\title{
Tax Potential vs. Tax Effort: \\ A Cross-Country Analysis of Armenia's \\ Stubbornly Low Tax Collection
}

Hamid R. Davoodi and David A. Grigorian 



\title{
IMF Working Paper
}

\author{
Middle East and Central Asia Department
}

Tax Potential vs. Tax Effort:

A Cross-Country Analysis of Armenia's Stubbornly Low Tax Collection

\author{
Prepared by Hamid R. Davoodi and David A. Grigorian ${ }^{1}$
}

Authorized for distribution by Saade Chami and Erik De Vrijer

May 2007

\begin{abstract}

\section{This Working Paper should not be reported as representing the views of the IMF.}

The views expressed in this Working Paper are those of the author(s) and do not necessarily represent those of the IMF or IMF policy. Working Papers describe research in progress by the author(s) and are published to elicit comments and to further debate.

Despite recording double digit growth since 2000, Armenia's tax-to-GDP ratio has been fairly stable at about $14 \frac{1}{2}$ percent. This paper catalogues a range of factors that may account for Armenia's stubbornly for tax collection by benchmarking Armenia's tax-to-GDP against some comparator countries and conducting an extensive econometric study of the main determinants of tax collection. We find empirical support for the hypothesis that the persistence of Armenia's low tax-GDP ratio can be traced to persistence of weak institutions and a large shadow economy. The gap between the potential and actual tax collection in Armenia could be as high as $6 \frac{1}{2}$ percent of GDP. We conclude with some policy recommendations that, if adopted, can boost revenue buoyancy.
\end{abstract}

JEL Classification Numbers: H2, H3, P52

Keywords: tax potential, tax collection, institutions, shadow economy, Armenia Authors’ E-Mail Addresses: hdavoodi@imf.org; dgrigorian@imf.org

\footnotetext{
${ }^{1}$ The authors would like to thank John Anderson, Hassan Al-Atrash, Marta Castello-Branco, Erik De Vrijer, Borja Gracia, Armineh Manookian, John Norregaard, and Ninke Oomes for comments. Remaining errors are our own.
} 


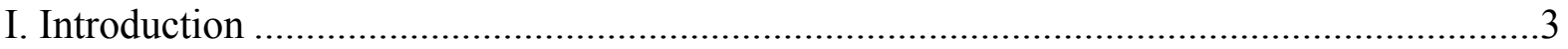

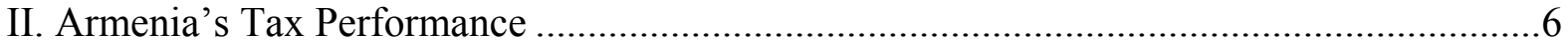

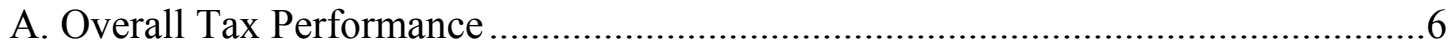

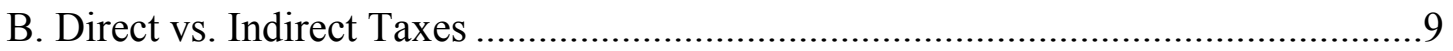

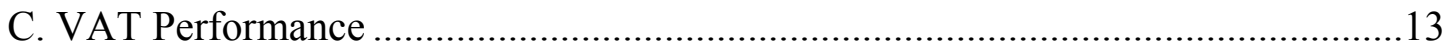

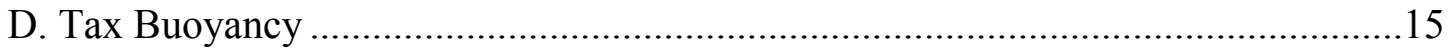

III. Tax Revenue Performance under Fund-Supported Programs, 1996-2006 .....................17

IV. Cross-Country Regression Analysis ......................................................................20

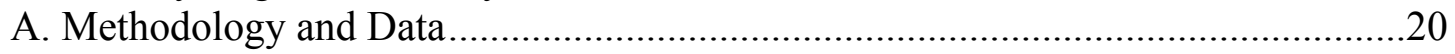

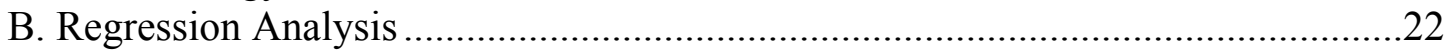

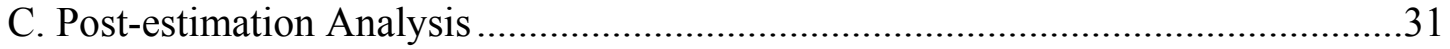

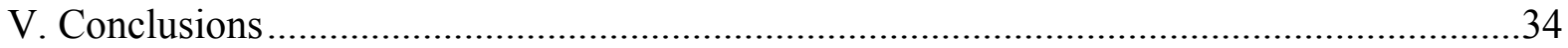

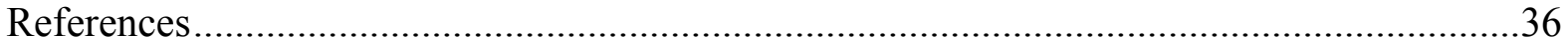

Tables

1. Armenia: Tax Revenues of Central Government........................................................6

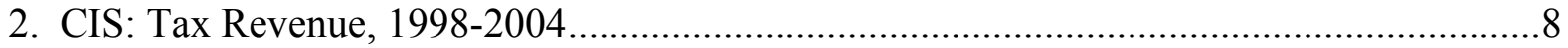

3. Armenia: Structure of Central Government's Tax Revenues........................................10

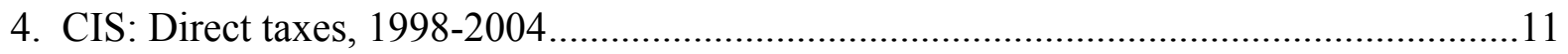

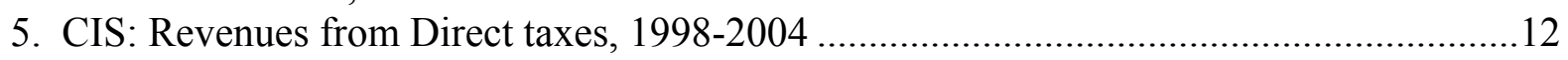

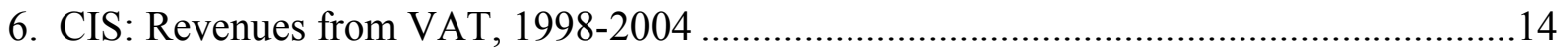

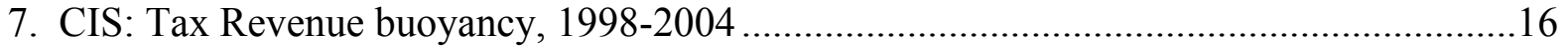

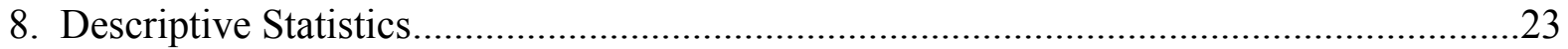

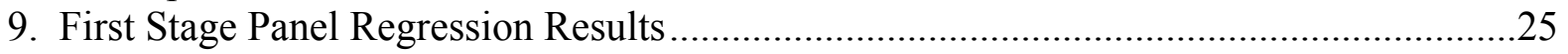

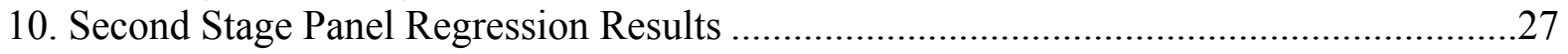

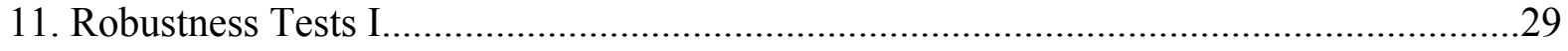

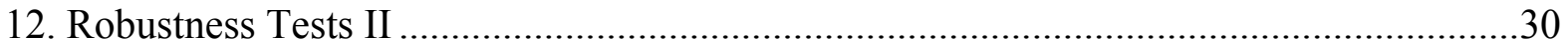

Figures

1. Central Government Tax Revenues, 1993-2004.......................................................

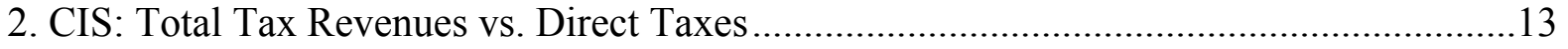

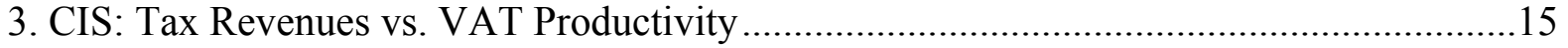

4. Tax Revenues in Armenia: Performance Under ESAF and PRGF..................................18

5. Actual and Potential Tax-to-GDP Ratios for Select Country Groupings, 1990-2004 .........32

6. Actual and Potential Tax Levels, and Tax Effort, 1996-2006 .......................................33

Box

1. Armenia's 2005-08 PRGF Program: Tax Policy and Tax and Customs Administration ...19 


\section{INTRODUCTION}

The Armenian economy has performed strongly by most macroeconomic criteria, particularly since 2000 . Economic growth has been robust but uneven. The central government's budget deficit has fallen from about 4 $\frac{1}{2}$ percent of GDP in 2000 to about 1 percent in 2006. Inflation has averaged about 3 percent a year. The overall poverty rate has continued the downward trend begun in the late 1990s, falling from 51 percent in 2001 to 35 percent in 2004. Armenia's progress on structural reforms has also been noticeable as it scores rather well on transition indicators, as measured by the European Bank for Reconstruction and Development, ahead of many countries in the Commonwealth of Independent States (CIS).

Yet, despite six consecutive years of double-digit nominal income growth and six consecutive years of real income growth in excess of 9 percent per year, the ratio of tax revenues to GDP has been fairly stable at about $14 \frac{1}{2}$ percent. It has been flat at 14 percent in 2003-04, despite record income growth in these years, edging up slightly in 2005-06. Despite the pick up in the last two years, Armenia's tax buoyancy remains low by regional and international standards. Tax collections in 2006 remain 1 1/2 percent of GDP lower than targeted in Armenia's Poverty Reduction Strategy Paper (PRSP) and about 1/2 percent of GDP below the programmed target in 2005 and 2006, respectively. ${ }^{2}$

As a result, the expenditure side of the budget remains constrained. The level of spending on social sector and public investment projects is low (by international standards), thereby limiting much-needed progress on the social front. Given the small size of the public sector, and the state of development of the private sector, market failures are frequent, and publicprivate partnerships (including with the Diaspora participation) are few and far between to overcome those failures. These factors undoubtedly have taken a toll on labor market conditions and the demographic situation: unemployment is still high despite rising real wages and emigration persists.

In this respect, several questions about tax revenue performance come to mind.

$>$ Is the lack of buoyancy a temporary phenomenon that will simply disappear once tax collection agencies catch up with the record income growth? If so, how long will it take to witness a catch up effect? To what extent is the failure to catch up due to the tax collection agencies' limited institutional capacity? Why is capacity limited despite the technical assistance delivered to the Armenian authorities over the last decade?

\footnotetext{
${ }^{2}$ The PRSP objective is to increase tax revenues by 0.4 percent of GDP each year for 2006-09 from the 2005 level, which was already below target by $1 \frac{1 / 2}{2}$ percent of GDP. The government's MediumTerm Expenditure Framework, drawn up in 2004-05, was less ambitious than the PRSP, showing smaller increases in the tax-to-GDP ratios in 2007-08 (an increase of 0.3 percent of GDP each year) but was more ambitious in the near term (indicating an increase of 0.7 percent of GDP in the 2005 budget relative to the outturn in 2004 and a much larger increase of 0.9 percent of GDP in 2006 relative to the 2005 budget).
} 
$>$ Is the unevenness of Armenia's high growth - concentrated in the agriculture, construction, and services sectors, which seem to have so far escaped making solid contributions to the tax collection effort - the primary reason for its low tax ratio or does this unevenness reflect a conscious public choice favoring sectors of the economy which contribute the most to overall growth, but not to tax collection?

> Is Armenia's relatively stable low tax-to-GDP ratio simply a legacy of past tax reforms which are destined to persist over time?

Is the low and stable tax-to-GDP ratio due only to poor tax policy (a narrow base caused by widespread exemptions and evasion), or is it also due to weak tax and customs administrations that do not effectively implement the existing tax policy or both?

$>$ Is the persistence of a low tax-to-GDP ratio the result of a vicious cycle of the low quality of public infrastructure (defined broadly to include the public institutional workings of a market economy), and the public's willingness to evade taxes and operate in the shadow economy, that depresses tax revenues and in turn limits the government's ability to provide high quality public infrastructure?

$>$ If the tax revenues collected do represent Armenia's full tax potential, then is it just a matter of public choice - namely, that Armenia is simply content to live with high economic growth, high remittances that finance private consumption, and low tax collection? $?^{3}$ After all, what are the benefits of collecting additional tax revenues beyond GDP growth if low tax collection and high economic growth go hand-in-hand and sizable remittances persist indefinitely in the formal or informal economy? What is the "appropriate" size of government in Armenia as measured by government spending, for example?

$>$ Does the tax effort in Armenia fall short of its potential as many seem to believe?

Clearly many factors account for the observed low and stable tax-to-GDP ratio and many observers of the Armenian economy, including the Armenian government, accept the proposition that for Armenia to make sufficient progress in its poverty reduction goals (as outlined in its PRSP), it has to increase its tax collection. Additional increases will also be necessary given the expected decline in foreign aid and concessional borrowing.

The primary aim of this paper is to identify a proximate set of factors that contribute to Armenia's stubbornly low tax-to-GDP ratio. We rely on several benchmark analyses of Armenia's tax-to-GDP ratio to analyze the impact of past tax reforms and tax revenue performance under Fund-supported programs, including the current program that covers $2005-08$. We then look extensively into the econometric determinants of Armenia's

\footnotetext{
${ }^{3}$ In 2005 remittances amounted to roughly 20 percent of GDP, far exceeding the tax-to-GDP ratio.
} 
tax revenues using a large panel data set of up to 141 countries over the 1990-2004 period. Econometric analysis and data limitations cannot possibly account for all the factors mentioned above. Our intention instead is to explain the determinants of tax revenues as much as possible using a conventional tax revenue model while taking into account particular features of the Armenian fiscal system and economic environment.

In particular, an important hypothesis of the paper is that the persistence of Armenia's low tax-GDP ratio is positively linked to the persistence of weak institutions and a large informal/shadow economy. This hypothesis is relevant to many countries, but we believe it is particularly relevant for Armenia. ${ }^{4}$ What ultimately matters in this process is whether there is the political will to reform institutions - defined broadly to include fiscal institutions, in particular the quality of tax and customs administration - and demonstrate to the public that higher tax revenues are being used to provide high quality public infrastructure, thus gaining the trust of the tax-paying public and boosting tax morale and trust in the fiscal system, all of which will eventually entail reducing the size of the shadow economy and widening the tax base.

The paper is structured as follows. Section II summarizes Armenia's track record on tax revenues and a selective review of tax reforms and tax and customs administration. Section III reviews tax revenue performance under various IMF-supported programs since the mid-1990s. Section IV looks at the determinants of tax revenues using an econometric analysis of a large panel of countries. This allows us to construct a measure of Armenia's tax effort, and analyze it over time as well as in comparison with other countries and with Armenia's tax potential. Finally, Section V summarizes the findings of the paper and draws some policy recommendations for improving tax collection in Armenia.

\footnotetext{
${ }^{4}$ As reported by Radio Free Europe/Radio Liberty Armenian Service, the head of the State Taxation Service division tasked with combating tax fraud was assassinated on September 7, 2006. In addition to being a high-level tax official, he was also a wealthy businessman, reportedly owning one of Armenia's two main liquefied gas companies, Goshgaz. Armenia to date has no legislation regulating conflicts of interest and no centralized public registry of corporate ownership.
} 


\section{Armenia's Tax Performance}

\section{A. Overall Tax Performance}

Armenia's tax revenue performance has varied considerably over the past decade, with stable tax-to-GDP ratio, averaging in recent years about 141/2 percent of GDP (Figure 1, Table 1). The highest ratio of tax revenue to GDP over the past decade was recorded in 1999 when it reached about 16 percent of GDP due to some unusual temporary factors. ${ }^{5}$ The decline in taxto-GDP ratios since 2000 was mirrored in all major tax categories. Collection of income taxes (personal and corporate income) showed the largest decline ( 0.5 percent of GDP), followed by excises ( 0.4 percent of GDP), and value-added tax (VAT) and custom duties (0.2 percent of GDP each). Presumptive income taxes and the so-called simplified tax (a turn-over based tax for small businesses) were the only two categories that showed increases during 2000-04. Of particular concern is the pronounced decline in the VAT and excise categories, which account for the bulk of tax revenue.

Table 1. Armenia: Tax Revenues of Central Government

(In percent of GDP)

\begin{tabular}{lrrrrrrrrrr}
\hline & 1994 & 1996 & 1997 & 1998 & 1999 & 2000 & 2001 & 2002 & 2003 & 2004 \\
\hline Tax revenue & 11.5 & 10.6 & 12.9 & 13.6 & 16.1 & 14.8 & 14.3 & 14.6 & 14.0 & 14.1 \\
$\quad$ Value-added tax & 2.7 & 3.3 & 4.9 & 6.2 & 6.9 & 6.5 & 6.7 & 7.0 & 6.6 & 6.2 \\
Excises & 0.4 & 1.7 & 2.3 & 2.0 & 2.2 & 2.5 & 2.6 & 2.6 & 2.4 & 2.1 \\
Enterprise profits tax & 5.7 & 2.5 & 2.0 & 1.3 & 2.2 & 2.0 & 1.3 & 1.3 & 1.1 & 1.7 \\
Personal income tax & 1.2 & 1.3 & 1.8 & 1.4 & 1.8 & 1.3 & 0.9 & 0.9 & 1.0 & 1.1 \\
Land tax & 0.2 & 0.3 & 0.0 & 0.0 & 0.0 & 0.0 & 0.0 & 0.0 & 0.0 & 0.0 \\
Customs duties & 0.4 & 0.9 & 1.3 & 1.1 & 0.8 & 0.8 & 0.8 & 0.7 & 0.7 & 0.7 \\
Other taxes & 0.8 & 0.5 & 0.4 & 1.1 & 1.7 & 1.3 & 1.4 & 1.4 & 1.4 & 1.3 \\
Presumptive Income Tax & $\ldots$ & 0.1 & 0.1 & 0.4 & 0.5 & 0.4 & 0.4 & 0.5 & 0.5 & 0.6 \\
Simplified Tax & $\ldots$ & $\ldots$ & $\ldots$ & $\ldots$ & $\ldots$ & 0.0 & 0.2 & 0.3 & 0.3 & 0.4 \\
Property tax & $\ldots$ & 0.1 & 0.0 & 0.0 & 0.0 & 0.0 & 0.0 & 0.0 & 0.0 & 0.0 \\
& & & & & & & & & & \\
Memorandum items: & & & & & & & & & & \\
$\quad$ Direct taxes 1/ & 6.9 & 3.9 & 3.8 & 2.7 & 4.0 & 3.3 & 2.3 & 2.2 & 2.1 & 2.8 \\
Indirect taxes & 4.6 & 6.8 & 9.1 & 10.9 & 12.1 & 11.5 & 12.1 & 12.4 & 11.9 & 11.3 \\
\hline
\end{tabular}

Source: Armenian Authorities; IMF staff estimates.

$1 /$ Consists of enterprise profit tax and personal income tax.

\footnotetext{
${ }^{5}$ Chief among these were a series of netting out operations and the extension of the 1999 tax year into 2000, which also affected tax revenues as recorded in that year. These factors may have added up to 2 percent of GDP in higher tax collection; see Gelbard and others (2005).
} 
Figure 1. Armenia: Central Government Tax Revenues, 1993-2004

\section{Total Tax Revenues \\ (percent of GDP)}

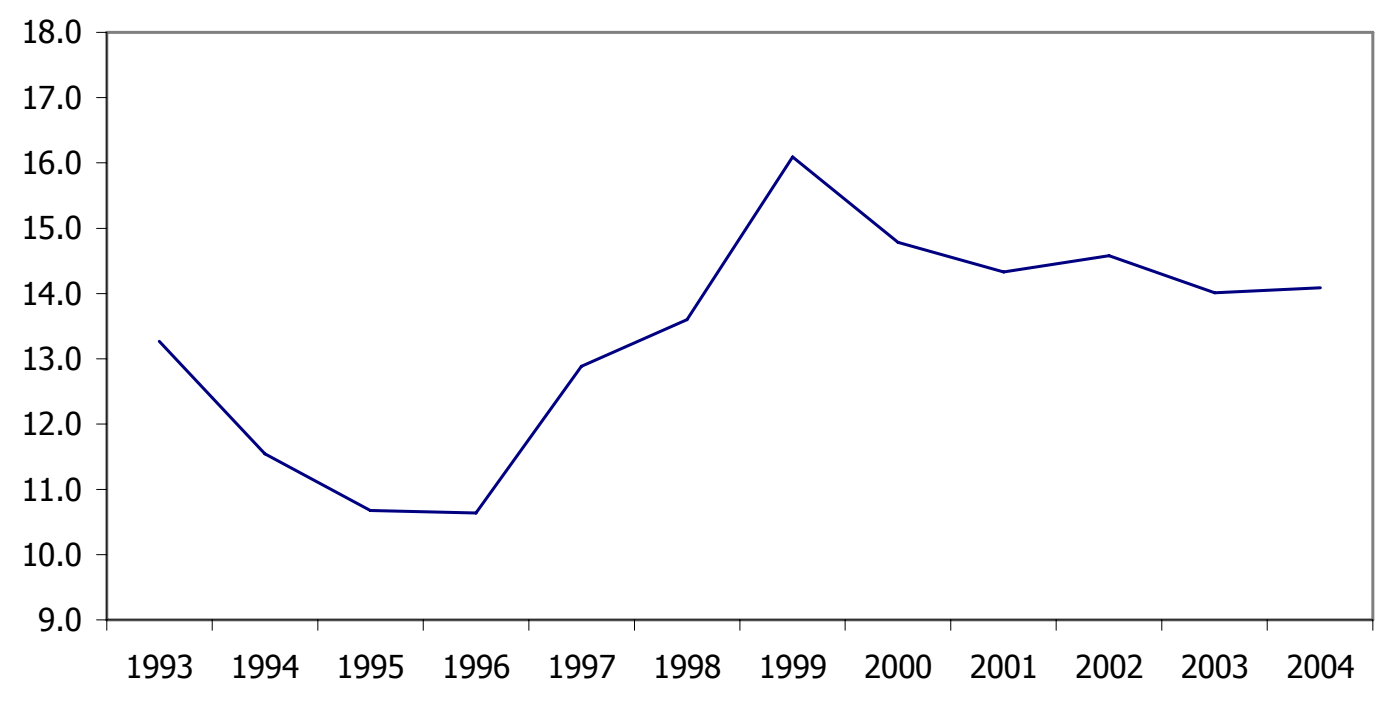

Direct Taxes

(percent of total taxes)

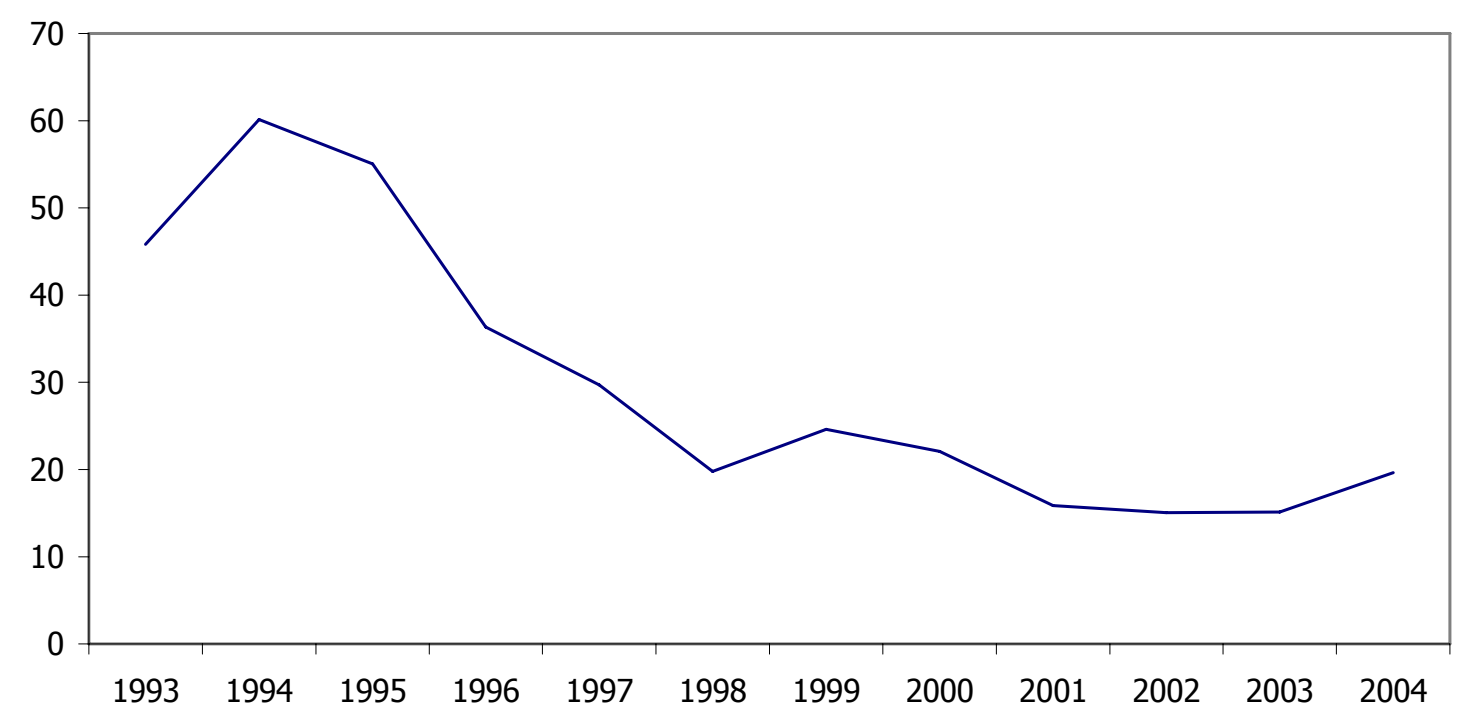

Source: Armenian authorities. 
Armenia's tax-to-GDP ratio is low in comparison with CIS countries, a useful benchmark to consider. ${ }^{6}$ Over the 1998-2004 period, the period common to all CIS countries for which comparable data could be assembled, Armenia recorded a tax-to-GDP ratio of $14 \frac{1}{2}$ percent. This is below the unweighted (arithmetic) average for the CIS 12 and the CIS 7 of 18.3 percent and 15.8 percent, respectively (Table 2 ). These discrepancies get larger if comparisons are made with CIS averages that exclude Armenia. Armenia's low tax-to-GDP ratio is also evident if the median is used instead of the unweighted average, particularly for the CIS 12. Armenia's relative position among the CIS countries does not change much using the more recent data over the 2000-04 period.

Table 2. CIS: Tax Revenue, 1998-2004 1/

(In percent of GDP)

\begin{tabular}{|c|c|c|c|c|c|c|c|c|c|}
\hline & 1998 & 1999 & 2000 & 2001 & 2002 & 2003 & 2004 & 1998-04 & 2000-04 \\
\hline Armenia * & 13.6 & 16.1 & 14.8 & 14.3 & 14.6 & 14.0 & 14.1 & 14.5 & 14.4 \\
\hline Azerbaijan * & 11.4 & 11.9 & 12.1 & 12.5 & 13.0 & 13.3 & 13.6 & 12.5 & 12.9 \\
\hline Belarus & 26.2 & 26.6 & 26.6 & 25.6 & 24.0 & 25.5 & 25.6 & 25.7 & 25.5 \\
\hline Georgia * & 12.8 & 12.1 & 12.2 & 12.5 & 12.7 & 12.2 & 15.4 & 12.9 & 13.0 \\
\hline Kazakhstan & 16.8 & 16.0 & 20.0 & 22.3 & 21.0 & 23.2 & 23.6 & 20.4 & 22.0 \\
\hline Kyrgyz Republic * & 14.7 & 12.3 & 11.7 & 12.4 & 13.9 & 14.2 & 14.9 & 13.4 & 13.4 \\
\hline Moldova * & 23.5 & 18.4 & 18.7 & 17.5 & 18.5 & 20.3 & 21.5 & 19.8 & 19.3 \\
\hline Russia & 24.4 & 24.1 & 27.4 & 27.8 & 27.1 & 26.3 & 28.2 & 26.5 & 27.4 \\
\hline Tajikistan * & 10.9 & 11.8 & 11.4 & 12.4 & 13.2 & 13.2 & 13.4 & 12.3 & 12.7 \\
\hline Turkmenistan & 13.5 & 13.3 & 17.9 & 18.3 & 14.4 & 13.4 & 14.5 & 15.0 & 15.7 \\
\hline Ukraine & 25.5 & 22.5 & 21.3 & 20.0 & 21.5 & 21.7 & 19.6 & 21.7 & 20.8 \\
\hline Uzbekistan * & 29.4 & 27.9 & 26.3 & 23.4 & 22.8 & 23.1 & 23.4 & 25.2 & 23.8 \\
\hline \multirow{2}{*}{\multicolumn{10}{|c|}{$\begin{array}{l}\text { Memorandum items: } \\
\text { Arithmetic average }\end{array}$}} \\
\hline & & & & & & & & & \\
\hline CIS 12 & 18.5 & 17.7 & 18.4 & 18.3 & 18.1 & 18.4 & 19.0 & 18.3 & 18.4 \\
\hline CIS 11 & 19.0 & 17.9 & 18.7 & 18.6 & 18.4 & 18.8 & 19.4 & 18.7 & 18.8 \\
\hline CIS 7 & 16.6 & 15.8 & 15.3 & 15.0 & 15.5 & 15.8 & 16.6 & 15.8 & 15.7 \\
\hline CIS 6 & 17.1 & 15.7 & 15.4 & 15.1 & 15.7 & 16.1 & 17.0 & 16.0 & 15.9 \\
\hline \multicolumn{10}{|l|}{ Median } \\
\hline CIS 12 & 15.7 & 16.1 & 18.3 & 17.9 & 16.6 & 17.3 & 17.5 & 17.4 & 17.5 \\
\hline CIS 11 & 16.8 & 16.0 & 18.7 & 18.3 & 18.5 & 20.3 & 19.6 & 19.8 & 19.3 \\
\hline CIS 7 & 13.6 & 12.3 & 12.2 & 12.5 & 13.9 & 14.0 & 14.9 & 13.4 & 13.4 \\
\hline CIS 6 & 13.7 & 12.2 & 12.2 & 12.5 & 13.5 & 13.8 & 15.1 & 13.2 & 13.2 \\
\hline
\end{tabular}

Source: Country officials and IMF staff estimates

1/ Excludes social security contributions. CIS 7 is marked by *. CIS 11 and CIS 6 exclude Armenia.

${ }^{6}$ The following country groupings will be used: CIS 12 (or CIS 11, which excludes Armenia); and CIS 7, which includes seven of the CIS 12 countries with low per capita income (or CIS 6, which excludes Armenia). See Table 2 for the list of countries in each grouping. Other benchmarks are considered in the next section. 
Among the CIS 7 countries, Armenia's tax-to-GDP ratio is higher than four, but well below the remaining two countries that are surprisingly poorer than Armenia. These four countries are Azerbaijan, Georgia, the Kyrgyz Republic, and Tajikistan while Moldova and Uzbekistan are the two countries with tax-to-GDP ratios of 19.8 percent and 25.2 percent, respectively. Ironically, these two countries have per capita incomes that are half as large as Armenia's. Therefore, differences in income alone cannot account for the difference in tax performance between Armenia and other countries. Section IV of the paper will address these issues more closely.

\section{B. Direct vs. Indirect Taxes}

Over time, Armenia's tax revenue has shown significantly less reliance on direct taxes, which tend to grow with income and enhance revenue buoyancy, and consequently more reliance on indirect taxes. The latter account for about 80 percent of tax revenues, up from 64 percent in the mid-1990s (Table 3). As a result, the share of direct taxes ${ }^{7}$ in total taxes declined by some 50 percent. This decline would have been much higher (at 60 percent), had it not been for an almost doubling of the collection of enterprise profit taxes in $2004 .^{8}$ The performance of VAT, excise taxes to some extent, and consumption taxes in general have contributed significantly to the rise in the share of indirect taxes since the mid-1990s. Reliance on more regressive indirect taxes in general increases inequity as low income households tend to have a higher marginal propensity to consume. ${ }^{9}$ Also, aggregate income growth, particularly if accrued primarily to higher income individuals, may not lead to significant tax collection if the tax system is not sufficiently progressive.

The decline in the importance of direct taxes is, to a large extent, a direct consequence of several tax policy reforms that were introduced in mid-2000 and may signify a trend towards a less equitable tax system in Armenia. These reforms were instituted by the Armenian authorities with the objective of improving the investment climate and stimulating economic growth. Growth accelerated, but there are many other factors that contributed to this economic growth. ${ }^{10}$ The tax reforms consisted of reducing tax rates on income and profits, accelerating depreciation allowances, generous profit tax holidays, a higher income tax exemption, a tripling of the VAT threshold, and the introduction of a simplified turn-over based tax for small businesses. As a result, the share of direct taxes in total tax revenues fell

\footnotetext{
${ }^{7}$ Direct tax is defined as personal income tax plus enterprise profit tax.

${ }^{8}$ This significant pick up in tax collection could be due to improvements in the operation of the large taxpayer unit at the State Tax Inspectorate.

${ }^{9}$ However, indirect taxes can be progressive if designed properly (e.g., exemption of food from taxes even though the rich would also benefit from such exemptions). Similarly, income taxes can made regressive if certain incomes are exempted (e.g., capital income) or certain tax incentives are terminated (e.g., removal of tax holidays).

${ }^{10}$ The fall in Armenia's real GDP in the early part of the transition was one of the largest among the transition economies and a rebound was long overdue.
} 
substantially. ${ }^{11}$ However, as shown by Joulfaian and Melikyan (2004), the overall marginal effective tax rates in Armenia remained well below statutory rates.

Table 3. Armenia: Structure of Central Government's Tax Revenues

(In percent of tax revenues)

\begin{tabular}{lcccccccccc}
\hline & 1994 & 1996 & 1997 & 1998 & 1999 & 2000 & 2001 & 2002 & 2003 & 2004 \\
\hline Tax revenue & 100.0 & 100.0 & 100.0 & 100.0 & 100.0 & 100.0 & 100.0 & 100.0 & 100.0 & 100.0 \\
$\quad$ Value-added tax & 23.5 & 30.6 & 38.0 & 45.9 & 43.0 & 43.7 & 46.5 & 47.8 & 47.4 & 44.2 \\
Excises & 3.9 & 16.1 & 18.0 & 14.9 & 13.7 & 17.2 & 18.4 & 17.8 & 17.2 & 15.2 \\
Enterprise profits tax & 49.6 & 23.8 & 15.5 & 9.4 & 13.5 & 13.3 & 9.3 & 8.8 & 7.7 & 12.0 \\
Personal income tax & 10.5 & 12.5 & 14.2 & 10.3 & 11.1 & 8.8 & 6.5 & 6.3 & 7.4 & 7.7 \\
Land tax & 1.9 & 2.8 & 0.0 & 0.1 & 0.0 & 0.0 & 0.0 & 0.0 & 0.0 & 0.0 \\
Customs duties & 3.7 & 8.4 & 10.2 & 8.1 & 5.1 & 5.7 & 5.8 & 4.9 & 4.7 & 4.7 \\
Other taxes & 7.0 & 4.3 & 3.2 & 8.1 & 10.3 & 8.5 & 9.5 & 9.4 & 9.8 & 9.1 \\
Presumptive Income Tax & $\ldots$ & 0.7 & 0.6 & 3.0 & 3.1 & 2.6 & 2.6 & 3.2 & 3.5 & 4.4 \\
Simplified Tax & $\ldots$ & $\ldots$ & $\ldots$ & $\ldots$ & $\ldots$ & 0.1 & 1.2 & 1.8 & 2.2 & 2.7 \\
Property tax & $\ldots$ & 0.9 & 0.3 & 0.2 & 0.2 & 0.1 & 0.1 & 0.0 & 0.0 & 0.0 \\
& & & & & & & & & & \\
Memorandum items: & & & & & & & & & & \\
$\quad$ Direct taxes 1/ & 60.1 & 36.3 & 29.7 & 19.8 & 24.6 & 22.1 & 15.9 & 15.1 & 15.1 & 19.7 \\
Indirect taxes & 39.9 & 63.7 & 70.3 & 80.2 & 75.4 & 77.9 & 84.1 & 84.9 & 84.9 & 80.3 \\
\hline
\end{tabular}

Source: Armenian Authorities; IMF staff estimates.

$1 /$ Consists of enterprise profit tax and personal income tax.

The large decline in the importance of direct taxes should raise concerns about striking the right balance between the three goals of fiscal policy, namely, the balance between efficiency in tax collection, equity, and macroeconomic stability. Although there are other factors at work and the tax reforms of the post-2000 period per se cannot fully account for the overall tax performance, there was nevertheless a large reversal in the share of direct taxes in tax revenues from 37 percent between 1994-2000 to 20 percent in the post-2000 period, equivalent to a drop of 1.7 percent of GDP. The increase in indirect taxes following these reforms more than compensated for the decline in direct taxes, but best practices in tax policy design indicate that with such a large reversal the balance of the tax system in Armenia between efficiency and equity considerations may have shifted more towards inequity. ${ }^{12}$ Needless to say, the issue of simplicity/transparency and quality of tax administration also weigh in these considerations, and need to be carefully considered.

\footnotetext{
${ }^{11}$ Broadening the coverage of direct taxes to include presumptive income and simplified taxes would increase the share of direct taxes, but its importance would remain well below mid-1990s.

${ }^{12}$ Existing measures of income/consumption inequality show a significant decline in inequality in Armenia over the past decade as observed by Gelbard and others (2005, Table 2.7). However, these do not measure inequality before and after tax.
} 
Armenia's small share of direct taxes in total tax revenues is perhaps one factor behind its low tax-to-GDP ratio vis-à-vis other CIS countries (Tables 4 and 5). The adverse impact of Armenia's 2000 tax reforms on performance of direct taxes, as discussed above, may be more discernable when it is seen in a cross-country perspective even though other countries may have also embarked on tax reforms at about the same time (e.g., Russia). Nevertheless, during 1998-2004, Armenia had the second and third-lowest share of direct taxes in tax revenues and GDP and its relative ranking did not change much during this period.

Table 4. CIS: Direct taxes, 1998-2004 1/

(In percent of tax revenues)

\begin{tabular}{lrrrrrrrrr}
\hline & 1998 & 1999 & 2000 & 2001 & 2002 & 2003 & 2004 & $1998-04$ & $2000-04$ \\
\hline Armenia * & 19.8 & 24.6 & 22.1 & 15.9 & 15.1 & 15.1 & 19.7 & 18.9 & 17.6 \\
Azerbaijan * & 38.2 & 36.6 & 38.7 & 31.9 & 32.7 & 34.6 & 39.2 & 36.0 & 35.4 \\
Belarus & 30.2 & 29.3 & 29.4 & 30.0 & 26.9 & 25.4 & 28.0 & 28.4 & 27.9 \\
Georgia * & 21.5 & 23.4 & 25.5 & 24.3 & 23.8 & 27.7 & 28.1 & 24.9 & 25.9 \\
Kazakhstan & 23.5 & 27.9 & 41.2 & 42.2 & 40.6 & 41.6 & 44.8 & 37.4 & 42.1 \\
Kyrgyz Republic * & 17.8 & 19.2 & 18.0 & 21.9 & 21.0 & 20.0 & 18.8 & 19.5 & 19.9 \\
Moldova * & 18.8 & 19.9 & 18.0 & 20.9 & 21.4 & 21.4 & 20.0 & 20.1 & 20.3 \\
Russia & 26.3 & 28.8 & 28.7 & 31.0 & 28.0 & 28.3 & 30.5 & 28.8 & 29.3 \\
Tajikistan * & 19.1 & 19.9 & 16.2 & 15.1 & 13.6 & 11.5 & 12.6 & 15.4 & 13.8 \\
Turkmenistan & 30.3 & 33.5 & 25.3 & 21.2 & 29.2 & 33.0 & 30.6 & 29.0 & 27.9 \\
Ukraine & 36.7 & 38.7 & 40.0 & 43.4 & 43.3 & 47.9 & 45.0 & 42.1 & 43.9 \\
Uzbekistan * & 33.3 & 31.9 & 28.8 & 32.8 & 32.1 & 29.4 & 29.0 & 31.1 & 30.4 \\
& & & & & & & & & \\
Memorandum items: & & & & & & & & & \\
Arithmetic average & & & & & & & & & \\
$\quad$ CIS 12 & 26.28 & 27.81 & 27.67 & 27.54 & 27.30 & 28.00 & 28.86 & 27.64 & 27.87 \\
$\quad$ CIS 11 & 26.87 & 28.10 & 28.18 & 28.60 & 28.42 & 29.17 & 29.69 & 28.43 & 28.81 \\
$\quad$ CIS 7 & 24.05 & 25.08 & 23.92 & 23.26 & 22.81 & 22.82 & 23.92 & 23.69 & 23.34 \\
$\quad$ CIS 6 & 24.77 & 25.16 & 24.22 & 24.49 & 24.10 & 24.10 & 24.63 & 24.50 & 24.31 \\
Median & & & & & & & & & \\
$\quad$ CIS 12 & 24.93 & 28.34 & 27.10 & 27.14 & 27.45 & 28.00 & 28.55 & 28.62 & 27.90 \\
$\quad$ CIS 11 & 26.32 & 28.80 & 28.67 & 29.98 & 28.01 & 28.32 & 28.98 & 28.81 & 27.93 \\
$\quad$ CIS 7 & 19.77 & 23.35 & 22.10 & 21.86 & 21.42 & 21.37 & 20.01 & 20.06 & 20.35 \\
$\quad$ CIS 6 & 20.28 & 21.65 & 21.78 & 23.08 & 22.61 & 24.53 & 24.07 & 22.48 & 23.12 \\
\hline
\end{tabular}

Source: Country officials and IMF staff estimates.

1/ Excludes social security contributions. CIS 7 is marked by *. CIS 11 and CIS 6 exclude Armenia. 
Table 5. CIS: Revenues from Direct taxes, 1998-2004 1/

(In percent of GDP)

\begin{tabular}{lrrrrrrrrr}
\hline & 1998 & 1999 & 2000 & 2001 & 2002 & 2003 & 2004 & $1998-04$ & $2000-04$ \\
Armenia * & 2.7 & 4.0 & 3.3 & 2.3 & 2.2 & 2.1 & 2.8 & 2.8 & 2.5 \\
Azerbaijan * & 4.4 & 4.3 & 4.7 & 4.0 & 4.2 & 4.6 & 5.3 & 4.5 & 4.6 \\
Belarus & 7.9 & 7.8 & 7.8 & 7.7 & 6.4 & 6.5 & 7.2 & 7.3 & 7.1 \\
Georgia * & 2.7 & 2.8 & 3.1 & 3.0 & 3.0 & 3.4 & 4.3 & 3.2 & 3.4 \\
Kazakhstan & 4.0 & 4.5 & 8.3 & 9.4 & 8.5 & 9.6 & 10.6 & 7.8 & 9.3 \\
Kyrgyz Republic * & 2.6 & 2.4 & 2.1 & 2.7 & 2.9 & 2.8 & 2.8 & 2.6 & 2.7 \\
Moldova * & 4.4 & 3.7 & 3.4 & 3.7 & 4.0 & 4.3 & 4.3 & 4.0 & 3.9 \\
Russia & 6.4 & 6.9 & 7.9 & 8.6 & 7.6 & 7.4 & 8.6 & 7.6 & 8.0 \\
Tajikistan * & 2.1 & 2.3 & 1.8 & 1.9 & 1.8 & 1.5 & 1.7 & 1.9 & 1.7 \\
Turkmenistan & 4.1 & 4.5 & 4.5 & 3.9 & 4.2 & 4.4 & 4.4 & 4.3 & 4.3 \\
Ukraine & 9.3 & 8.7 & 8.5 & 8.7 & 9.3 & 10.4 & 8.8 & 9.1 & 9.1 \\
Uzbekistan * & 9.8 & 8.9 & 7.6 & 7.7 & 7.3 & 6.8 & 6.8 & 7.8 & 7.2 \\
Memorandum items: & & & & & & & & & \\
Arithmetic average & & & & & & & & & \\
$\quad$ CIS 12 & 5.0 & 5.1 & 5.3 & 5.3 & 5.1 & 5.3 & 5.6 & 5.2 & 5.3 \\
$\quad$ CIS 11 & 5.2 & 5.2 & 5.4 & 5.6 & 5.4 & 5.6 & 5.9 & 5.5 & 5.6 \\
$\quad$ CIS 7 & 4.1 & 4.1 & 3.7 & 3.6 & 3.6 & 3.7 & 4.0 & 3.8 & 3.7 \\
$\quad$ CIS 6 & 4.3 & 4.1 & 3.8 & 3.8 & 3.9 & 3.9 & 4.2 & 4.0 & 3.9 \\
Median & & & & & & & & & \\
$\quad$ CIS 12 & 4.2 & 4.4 & 4.6 & 3.9 & 4.2 & 4.5 & 4.9 & 4.4 & 4.4 \\
CIS 11 & 4.4 & 4.5 & 4.7 & 4.0 & 4.2 & 4.6 & 5.3 & 4.5 & 4.6 \\
CIS 7 & 2.7 & 3.7 & 3.3 & 3.0 & 3.0 & 3.4 & 4.3 & 3.2 & 3.4 \\
CIS 6 & 3.6 & 3.2 & 3.3 & 3.4 & 3.5 & 3.9 & 4.3 & 3.6 & 3.7 \\
\hline
\end{tabular}

Source: Country officials and IMF staff estimates.

1/ Excludes social security contributions. CIS 7 is marked by *. CIS 11 and CIS 6 exclude Armenia.

Casual cross-country comparisons show that Armenia's actual tax-to-GDP ratio falls below its potential by as much as $1 \frac{1}{2}$ percent of GDP, suggesting significant room for broadening the income tax base and strengthening tax administration. Figure 2 plots tax-to-GDP ratios against the share of direct taxes in total tax revenues for CIS 12 countries during 1998-2004. It shows the presence of a positive relationship between these two variables. Over the period, Armenia recorded a tax-to-GDP ratio of $14 \frac{1}{2}$ percent whereas the fitted relationship shows that it should have had a tax-to-GDP ratio of 16 percent. This shortfall of $1 \frac{1}{2}$ percent of GDP is crude as there are many other factors that influence tax revenues, an issue that is systematically analyzed in Section IV of the paper. Nevertheless, the relationship suggests that there is significant room for increasing income taxes either through broadening the base, strengthening administration or both. 
Figure 2. CIS: Total Tax Revenues vs. Direct Taxes

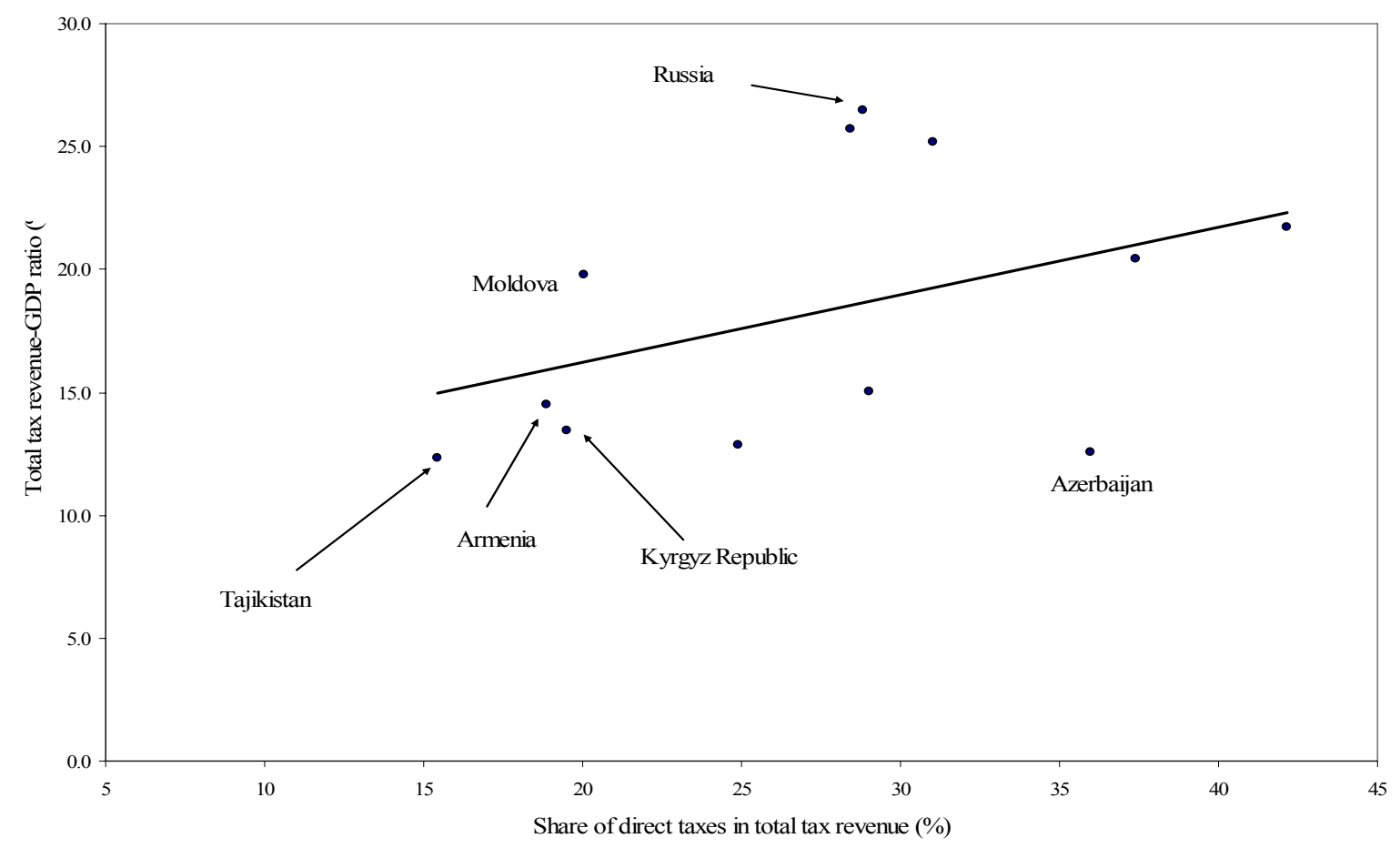

\section{VAT Performance}

Although declining since 2001 (except for a brief spike in 2002, see Table 6), Armenia's VAT collection is much better than its income tax collection when compared with other CIS countries: it accounts for some 45 percent of tax revenues and $6 \frac{1}{2}$ percent of GDP. Among the CIS 12 countries and with the exception of Moldova and the Kyrgyz Republic, Armenia has the highest share of its tax revenues originating from VAT. Its VAT collection in terms of GDP exceeds that of eight CIS countries and is only below Moldova, Belarus, and Uzbekistan.

Nevertheless, as in the case of income taxes, Armenia's VAT collection is below its full potential, suggesting significant room for further tax policy and tax administration reforms. Figure 3 plots the tax-to-GDP ratio against VAT productivity for CIS countries. ${ }^{13}$ The fitted relationship is positive and statistically significant, suggesting that as the efficiency of VAT collection increases so does the tax-to-GDP ratio. ${ }^{14}$ The relationship shows that Armenia's potential for higher tax revenues, given its VAT productivity, exceeds actual tax collection

${ }^{13}$ VAT productivity is defined as the ratio of VAT revenues to GDP or consumption divided by the standard VAT rate. A higher number signifies a more efficient VAT system with fewer exemptions.

${ }^{14}$ The estimated regression is tax-to-GDP ratio $=4.11+46.84 *$ VAT productivity, $\mathrm{R}^{2}=0.45$ with a tratio of 2.74 on the estimated coefficient of VAT productivity. 
by as much as 5 percent of GDP. ${ }^{15}$ This casual empiricism suggests that by improving its VAT productivity, say through lower exemptions, Armenia can ride up the fitted relationship and boost its revenues.

Table 6. CIS: Revenues from VAT, 1998-2004 1/

(In percent of GDP)

\begin{tabular}{|c|c|c|c|c|c|c|c|c|c|}
\hline & 1998 & 1999 & 2000 & 2001 & 2002 & 2003 & 2004 & 1998-04 & $2000-04$ \\
\hline Armenia * & 6.2 & 6.9 & 6.5 & 6.7 & 7.0 & 6.6 & 6.2 & 6.6 & 6.6 \\
\hline Azerbaijan * & 4.2 & 4.2 & 4.1 & 4.8 & 5.5 & 5.7 & 5.4 & 4.8 & 5.1 \\
\hline Belarus & 8.8 & 8.7 & 9.0 & 8.4 & 8.3 & 7.9 & 7.7 & 8.4 & 8.3 \\
\hline Georgia * & 4.4 & 4.4 & 4.8 & 5.4 & 5.6 & 4.5 & 6.3 & 5.0 & 5.3 \\
\hline Kazakhstan & $\ldots$ & 4.4 & 4.4 & 4.9 & 4.7 & 5.0 & 4.4 & 4.6 & 4.7 \\
\hline Kyrgyz Republic * & 5.8 & 4.6 & 4.6 & 5.7 & 6.4 & 6.6 & 7.3 & 5.8 & 6.1 \\
\hline Moldova * & 12.3 & 7.6 & 8.4 & 7.9 & 9.0 & 10.1 & 10.7 & 9.4 & 9.2 \\
\hline Russia & 6.4 & 5.9 & 6.3 & 7.2 & 7.0 & 6.7 & 6.4 & 6.5 & 6.7 \\
\hline Tajikistan * & 1.9 & 2.3 & 2.5 & 3.4 & 4.8 & 5.1 & 5.7 & 3.7 & 4.3 \\
\hline Turkmenistan & 5.1 & 5.1 & 6.7 & 6.2 & 5.4 & 5.2 & 5.6 & 5.6 & 5.8 \\
\hline Ukraine & 7.3 & 6.4 & 5.6 & 5.1 & 6.0 & 4.7 & 4.3 & 5.6 & 5.1 \\
\hline Uzbekistan * & 9.4 & 7.3 & 7.5 & 6.5 & 6.0 & 5.5 & 5.5 & 6.8 & 6.2 \\
\hline \multicolumn{10}{|l|}{ Memo: } \\
\hline \multicolumn{10}{|l|}{ Arithmetic average } \\
\hline CIS 12 & 6.5 & 5.7 & 5.8 & 6.0 & 6.3 & 6.1 & 6.3 & 6.1 & 6.1 \\
\hline CIS 11 & 6.6 & 5.5 & 5.8 & 6.0 & 6.2 & 6.1 & 6.3 & 6.0 & 6.1 \\
\hline CIS 7 & 6.3 & 5.3 & 5.5 & 5.8 & 6.3 & 6.3 & 6.7 & 6.0 & 6.1 \\
\hline CIS 6 & 6.3 & 5.1 & 5.3 & 5.6 & 6.2 & 6.3 & 6.8 & 5.9 & 6.0 \\
\hline \multicolumn{10}{|l|}{ Median } \\
\hline CIS 12 & 6.2 & 5.5 & 5.9 & 6.0 & 6.0 & 5.6 & 5.9 & 5.7 & 5.9 \\
\hline CIS 11 & 6.1 & 5.1 & 5.6 & 5.7 & 6.0 & 5.5 & 5.7 & 5.6 & 5.8 \\
\hline CIS 7 & 5.8 & 4.6 & 4.8 & 5.7 & 6.0 & 5.7 & 6.2 & 5.8 & 6.1 \\
\hline CIS 6 & 5.1 & 4.5 & 4.7 & 5.5 & 5.8 & 5.6 & 6.0 & 5.4 & 5.7 \\
\hline
\end{tabular}

Source: Country officials and IMF staff estimates

1/ Excludes social security contributions. CIS 7 is marked by *. CIS 11 and CIS 6 exclude Armenia.

${ }^{15}$ A similar caveat to income tax calculation applies here as well. 
Figure 3. CIS: Tax Revenues vs. VAT Productivity

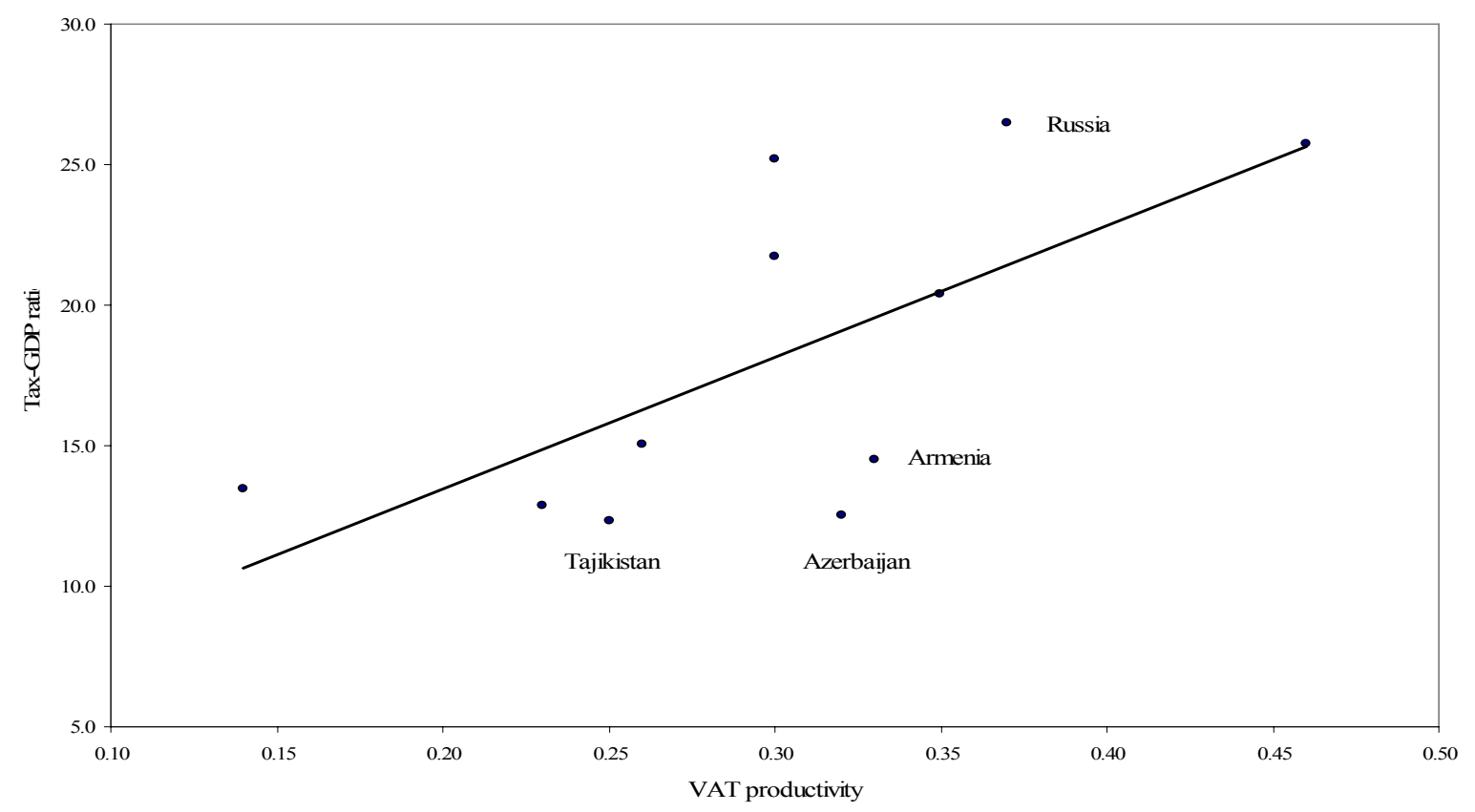

\section{Tax Buoyancy}

Armenia's tax revenue buoyancy is low compared with other CIS countries, despite doubledigit economic growth registered since 2000, suggesting another factor for its low tax-toGDP ratio (Table 7). ${ }^{16}$ Since 2000, GDP has grown strongly each year and yet revenues have not kept up pace with economic growth. Table 7 reports revenue buoyancy for three types of taxes (total, direct, and VAT) for Armenia and other CIS countries over the 1998-2004 period. Armenia's record on tax buoyancy is poor as reflected in the following observations.

Armenia has revenue buoyancies that are below unity and below all four CIS averages for all three categories of taxes.

In Armenia, VAT has the highest buoyancy, followed by total taxes and direct taxes.

\footnotetext{
${ }^{16}$ Tax revenue buoyancy is defined as the elasticity of tax revenues with respect to nominal GDP. The elasticity summarizes the impact of both tax policy (base effect with an unchanged tax

administration) as well as tax administration (efficiency in raising one additional dram from the same base with an unchanged tax policy) .
} 
At 0.55 , Armenia's direct taxes have the lowest buoyancy among all CIS countries and the three categories of taxes. ${ }^{17}$ This buoyancy increases to 0.69 if presumptive income tax is also counted as part of direct taxes.

Table 7. CIS: Tax Revenue buoyancy, 1998-2004 1/

\begin{tabular}{lrrr}
\hline & Total taxes & VAT & Direct taxes \\
\hline Armenia * & 0.93 & 0.97 & 0.55 \\
Azerbaijan * & 1.19 & 1.39 & 1.15 \\
Belarus & 0.99 & 0.97 & 0.96 \\
Georgia * & 1.22 & 1.41 & 1.57 \\
Kazakhstan & 1.34 & 1.04 & 1.71 \\
Kyrgyz Republic* & 1.02 & 1.27 & 1.13 \\
Moldova * & 0.96 & 0.99 & 1.05 \\
Russia & 1.08 & 1.04 & 1.14 \\
Tajikistan * & 1.12 & 1.65 & 0.82 \\
Turkmenistan & 1.01 & 1.01 & 1.02 \\
Ukraine & 0.83 & 0.59 & 1.03 \\
Uzbekistan * & 0.88 & 0.76 & 0.84 \\
Memorandum items: & & & \\
Arithmetic average & & & \\
$\quad$ CIS 12 & & & \\
CIS 11 & 1.05 & 1.09 & 1.08 \\
CIS 7 & 1.06 & 1.10 & 1.13 \\
CIS 6 & 1.05 & 1.21 & 1.02 \\
Median & 1.07 & 1.25 & 1.09 \\
CIS 12 & & & \\
CIS 11 & 1.02 & 1.03 & 1.04 \\
CIS 7 & 1.02 & 1.04 & 1.05 \\
CIS 6 & 1.02 & 1.27 & 1.05 \\
\hline Source: County ofic & 1.33 & 1.09 \\
\hline
\end{tabular}

Source: Country officials and IMF staff estimates.

1/ Excludes social security contributions. Each entry denotes elasticity of a revenue category with respect to nominal GDP. CIS 7 is marked by *. CIS 11 and CIS 6 exclude Armenia.

\footnotetext{
${ }^{17}$ A buoyancy of 0.55 means, for example, that if GDP increases by 1 percent, direct taxes increase by 0.55 percent, which results in a declining tax-to-GDP ratio.
} 


\section{Tax Revenue Performance under Fund-Supported Programs, 1996-2006}

Armenia's tax performance has generally fallen short of program projections under both the Enhanced Structural Adjustment Facility (ESAF, 1996-99) and the Poverty Reduction and Growth Facility (PRGF, 2001-04) programs. ${ }^{18}$ Looking back, Fund-supported programs on average envisaged annual tax revenues about $1 / 2$ percent of GDP higher than the actual outcome (Figure 4), reflecting the perception that Armenia has sizable room to improve tax collection, a long-held assessment that dates back to the early years of the transition.

However, a major difference between the ESAF- and PRGF-supported programs is a rising tax-to-GDP ratio under the former and a broadly stable ratio under the latter. The rising trend during the ESAF period reflects, among other things, the transition from a low tax base and a shift in Armenia's VAT collection in 1997-98 from an origin to a destination principle for trade within CIS countries. This shift was an important tax reform as it may have permanently increased Armenia's tax revenues by as much as 3 percent of GDP.

On average, tax revenues during the PRGF period were higher than in the ESAF period by about 1 percent of GDP, slightly exceeding programmed tax revenue increases. The improved tax collection during the PRGF period vis-à-vis the ESAF period would double to 2 percent of GDP if the unusually high collection of tax revenues in 1999 were excluded. Netting out the additional 2 percent of GDP from the 1999 data (see footnote 5 above) would result in a tax-to-GDP ratio of 14.1 percent which represents a gradual rise in tax collection from the last ESAF year to a relatively stable, but higher, tax performance during the PRGF period.

There is no statistically significant difference between ESAF and PRGF programs with regard to programmed tax revenue performance, reflecting the expectation that Armenia has potential for significantly improving its tax collection. During the ESAF period, the difference between the programmed tax revenue and the outcome amounted to 0.65 percent of GDP whereas during the PRGF period this difference stood at 0.45 percent of GDP, a statistically insignificant difference. However, a difference between the two programs is a pronounced narrowing of the differential between programmed tax revenue and the outcome during the PRGF program. The narrowing of the differential reflects, among other things:

the expectation that the programmed fiscal consolidation was to be accomplished primarily through expenditure compression rather than revenue mobilization; this expectation later materialized (see Gelbard, et. al., 2005);

$>$ a gradual adjustment of unrealistic (with hindsight) expectations of revenue mobilization to the realities of persistently weak tax and customs administration; and

$>$ the time-consuming process of understanding the full revenue effects of the ongoing tax policy reforms.

\footnotetext{
${ }^{18}$ In May 2005, the Executive Board of the IMF approved a second PRGF program for Armenia, covering the $2005-08$ period.
} 
Figure 4. Tax Revenues in Armenia: Performance Under ESAF and PRGF (percent of GDP)

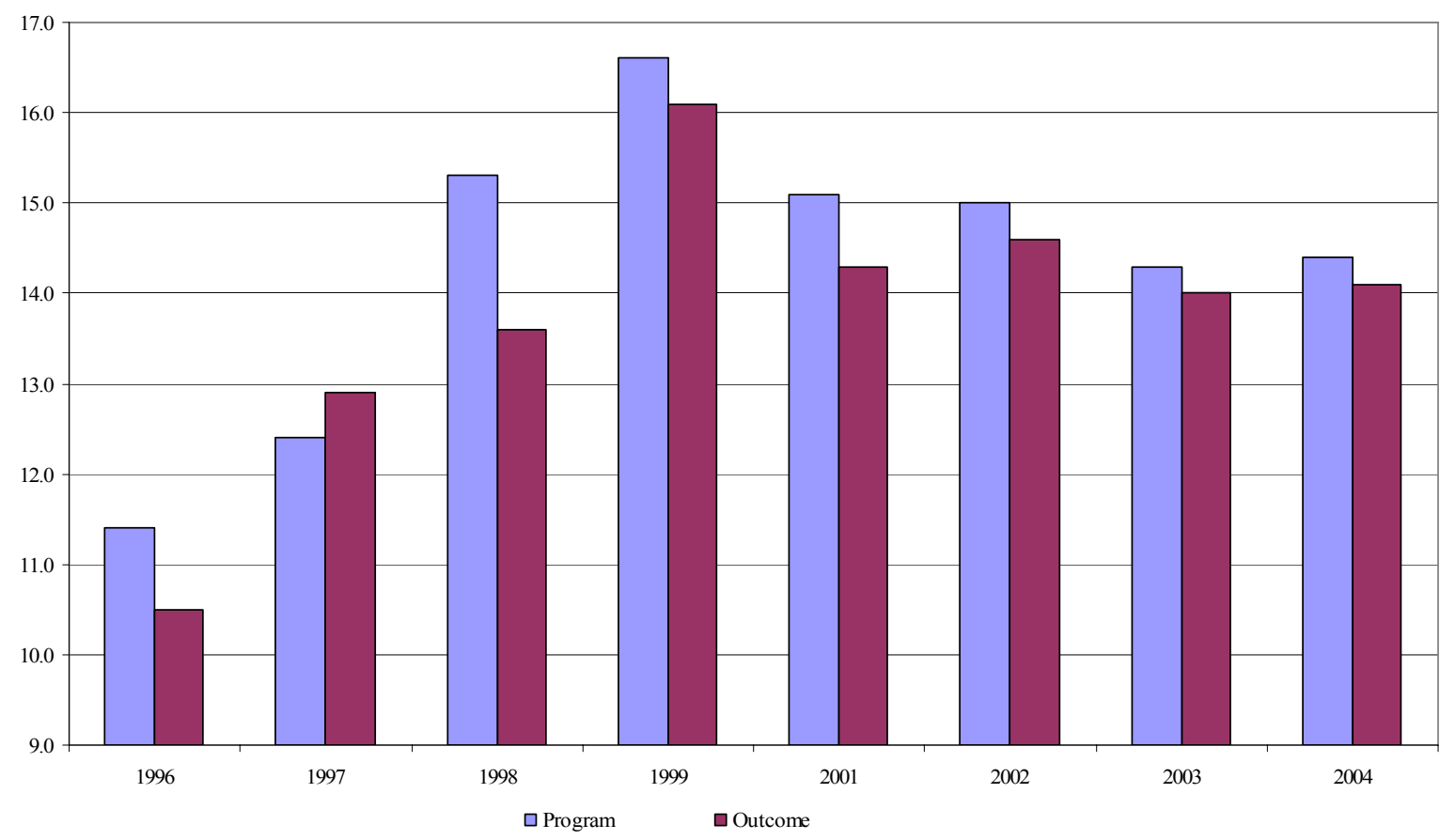

Several competing explanations account for the narrowing of the differential between programmed tax revenue and the outcome during the PRGF program. The narrowing could be due to setting lower programmed tax revenues ex ante, higher ex post revenue performance, or both. The authorities continued to set programmed tax revenues higher than actual or past performance on the expectation that these would then necessitate a stronger effort on the part of the agency to increase tax collection thus bringing the outcome closer to the programmed tax collection. This two-way mechanism then became more entrenched as it built momentum in tax collection and in the expectations of higher expenditure needs that would have addressed major social and infrastructure needs in Armenia. However, there are also additional reasons for setting higher programmed tax revenue targets relative to GDP (e.g., programmed real GDP growth was often lower than actual results).

Setting tax revenue targets relative to GDP as compared with setting them in nominal terms (i.e., in Armenian drams) raises several issues that highlight the role of tax and customs administration in Armenia and their complex interaction with tax revenue performance.

First, as IMF staff have noted, tax revenue targets have been met in nominal terms. ${ }^{19}$ On the surface, one may interpret that the dram equivalent of tax revenue targets is being collected and

${ }^{19}$ IMF Country Report No 0.05/178, p.8, footnote 3. 
there are, therefore, no inherent problems in meeting those targets. However, actual collection does not in any way demonstrate how much Armenia can potentially collect in taxes.

Second, tax revenue targets relative to GDP, a proper benchmark for the overall performance of tax revenues, ${ }^{20}$ also reflect assumptions about improvements in tax and customs administration and the underlying de jure measures that will bring about the targeted/programmed tax revenues. These expectations typically show up ex ante in a revenue buoyancy which, as explained earlier, measures performance relative to GDP. Revenue targets under Fund-supported programs generally expected a higher revenue buoyancy than those shown in Table 7.

Third, Armenia's high economic growth since 2000 and its poor tax performance not only reflects the impact of tax policies enacted after 2000, but also the prevalence of exemptions (in VAT, income taxes, generous profit tax holidays); widespread use of a complex set of presumptive direct and indirect taxes, which provide ample incentives for negotiations between the tax collector and the taxpayer and bribery; as well as general weakness in tax and customs administration, all of which result in weak links between de jure and de facto tax and customs administration measures. Hence, efforts to boost tax collection would require major efforts in the areas of tax and customs administration and less so in tax policy $\left(\right.$ See Box 1). ${ }^{21}$

\section{Box 1: Armenia's 2005-08 PRGF Program: Tax Policy and Tax and Customs Administration}

Reflecting the complexities and the record of Armenia's tax collection, improvements in tax and customs administration and tax policy are seen by the Armenian government and Fund staff as the cornerstone of fiscal policy in the second PRGF program (2005-08). The program consists of 18 measures, of which:

$>$ six tax policy measures are designed to broaden the tax base without raising tax rates, including limiting VAT exemptions and limiting VAT refund payments. Some of these measures are also de facto tax administration measures;

$>$ seven tax administration measures, including improving tax audits, improving the collection of tax arrears, improving the VAT refund mechanism, and strengthening the capacity of the large taxpayer unit; and

$>$ five customs administration measures, including facilitating the self-assessment of importers and expanding the use of information technology (ASYCUDA) to all customs houses.

The projected impact of these measures amounts to $1 / 2$ percent in tax-to-GDP each program year, implying rising revenue buoyancies.

Source: IMF Country Report No. 05/178.

${ }^{20}$ In principle, each tax has its own base and each base has to reflect various exemptions, deductions, etc. In practice, nominal GDP is used as an approximation to the base for overall tax revenues.

${ }^{21}$ While Armenia's tax policy could be further improved, this point reflects a general understanding that, by comparison, it is well designed with low and uniform rates. 


\section{Cross-COUnTry Regression ANALYSIS}

\section{A. Methodology and Data}

There is a large body of literature on tax revenue potential in developing countries (e.g., Bahl, 1971; Tanzi, 1987; Leuthold, 1991; and Stotsky and WoldeMariam, 1997; among others). However, there is little research that looks at institutional quality as a determinant of tax collection and potential. ${ }^{22}$ In addition to conventional determinants of tax revenues, this small, but growing literature regards quality of institutions and governance as important factors behind the poor tax collection in many countries. These factors are thought to influence tax revenue through their contribution to tax evasion, improper tax exemptions, and weak tax administration (Tanzi and Davoodi, 1997). More and more studies find that any successful tax reform should be rooted in a strong political will to reform (Bird, 2004), and that a country's tax record reflects its political or 'societal' institutions (Alm and MartinezVazquez, 2003). Indeed, as Bird, Martinez-Vazquez, and Torgler (2004) conclude, a legitimate and responsive state- one that secures the rule of law and keeps corruption under control - appears to be an essential precondition for a more adequate tax collection effort.

In addition to the role of institutions, this paper also focuses on the size of the informal (or shadow) economy as a determinant of tax revenue. The agents' incentives to "go formal" and pay taxes are among other things also influenced by the quality and quantity of public services. A vicious circle is likely to exist, therefore, whereby agents' unwillingness to pay taxes results in the government's inability to provide adequate quality/quantity of public services, thus further reducing the incentives to pay taxes.

Following the tax effort literature, ${ }^{23}$ we define the reduced form equation for a cross-country panel regression in the following format: ${ }^{24}$

$$
y_{i t}=\alpha+\beta \cdot X_{i t}+u_{i}+\varepsilon_{i t}
$$

where $y_{i t}$ is the total tax revenue as a percent of GDP in a country $i$ at time $t, \alpha$ is the "global" constant, $u_{i}$ is the country-specific error term, $\varepsilon_{i t}$ is the mean-zero sample-wide error term, and $\beta$ is the vector of coefficients on the vector of parameters that influence the tax-to-GDP ratio, $X_{i t}$, which itself is comprised as follows:

\footnotetext{
${ }^{22}$ Exceptions perhaps are Tanzi and Davoodi (2000) and Bird, Martinez-Vazquez, and Torgler (2004), which, however, employ a cross-sectional approach as opposed to a panel set-up, which is the approach used in this study.

${ }^{23}$ See, for example, Bahl (1971), Tanzi (1987), Stotsky and WoldeMariam (1997), Bird, MartinezVazquez, and Torgler (2004) and Hudson and Teere (2004).

${ }^{24}$ Leuthold (1991), for instance, arrives at a similar specification using an aggregate welfare maximization framework.
} 


$$
X_{i t}=\left(G D P P C_{i t}, I N S_{i t}, I N F_{i t}, A G R I C_{i t}, T_{R A D E_{i t}}, O_{i t}, U R B A N_{i t}, S H A D O W_{i t}\right)
$$

where GDPPC is the PPP-adjusted GDP per capita;

INS is a measure of institutional quality;

$I N F$ is the rate of consumer price inflation;

$A G R I C$ is the share of agriculture in GDP;

$T R A D E$ is the ratio of exports plus imports to GDP;

$O I L$ is a dummy variable for fuel exporters; ${ }^{25}$

$U R B A N$ is the share of the urban population in a country's total population; and

SHADOW is a measure of shadow economic activity, taken in percent of GDP.

Income level, GDPPC, is used as a proxy for the level of a country's development, and it is expected to be positively correlated with the government's ability to collect taxes and the citizens' ability to pay them. Quality of institutions, INS, which captures various aspects of the governance of the public sector, such as corruption, rule of law, the extent of rent seeking and regulatory burden, is expected to be positively associated with tax revenue. A higher value of INS indicates a higher quality of institutions. To proxy for the quality of a country's macroeconomic policies and to also capture any direct impact of inflation on tax collectionthrough the effect on consumption and investment, and subsequently on their related tax categories - we also included $I N F$ as a regressor. A negative coefficient is expected for this variable. The presence of $A G R I C$ in equation 1 is dictated by general (administrative and political economy) difficulties of taxing agriculture and the intentions of many governments to either provide tax exemptions or subsidies (or both). The presence of a large rural sector also reduces the demand for government services, since many public sector activities are city-based (Tanzi, 1992). Therefore, to proxy for the demand for public services, we included the share of the urban population, URBAN, in our regressions. Given different levels of agricultural productivity across countries, a large agricultural sector share does not necessarily indicate a smaller urban population. Hence the need to control for urban population separately, as an indicator of the demand for government services. A positive coefficient is expected for $U B R A N$ to the extent that higher demand for public services ceteris paribus requires higher tax revenue.

Given the relative ease in taxing foreign trade compared to domestic activities, we follow the literature to include TRADE in the regressions and expect it to have a positive impact on tax collection. The inclusion of $O I L$ in the regressions is justified on the same grounds as the ease in taxing fuel- (and generally, natural resource extraction-) related activities, which is likely to generate more tax revenue (per unit of output or value added) than non-fuel

\footnotetext{
${ }^{25}$ This variable takes a value of 1 if the country is a fuel exporter (i.e., share of oil and gas in total exports exceeds 40 percent), and 0 otherwise. While arguably inferior by nature to the corresponding continuous variable, this dummy variable is likely to paint a more realistic picture of the country's genuine fuel taxable base. This is because for some countries the reported values for fuel-to-total exports contain only re-export and/or transit of fuels, instead of production and genuine export of fuel products, with different implications for the government's ability to tax them. In addition, for some countries, where the data on fuel exports were not available, we were nevertheless able to deduce the value for OIL based on publicly available production data.
} 
activities. A negative coefficient is expected for the $O I L$ variable to the extent that direct or indirect taxes raise little revenues in countries with abundant oil reserves. In summary, it is useful to think of GDPPC, AGRIC, TRADE, and $O I L$ as proxies for various structural components of the economy's tax base.

Last but not least, to proxy for low tax morale and willingness to pay, we used SHADOW as an explanatory variable. The latter is shown to be correlated with low tax morale (see, for example, Alm and Torgler, 2004) partly through lower moral cost of tax evasion and otherwise weaker motivation to pay taxes. We expect countries with a large shadow economy to have smaller levels of tax-to-GDP.

While lacking solid theoretical foundations, the approach outlined above is rather attractive because of its ability to provide a simple empirical framework to measure a country's tax effort vis-à-vis that of its peers (Tanzi and Zee, 2000). The predicted/fitted values of the dependent variable obtained through equation 1 will thus measure the country's tax potential, while the ratio of the actual to predicted tax revenue will be a proxy for the level of tax effort.

The analysis will be based on publicly available data on up to 141 countries for the period 1990-2004 downloaded from the IMF's Government Financial Statistics database. Where necessary, these data were complemented by those contained in various IMF staff reports and other publications, as well as countries' official websites. Indicators of institutional quality used in the paper are from the International Country Risk Guide (ICRG). A more complete list of data sources and their statistical properties is provided in Table 8.

\section{B. Regression Analysis}

Before we proceed with the discussion of the main regression results, note that some righthand-side variables in equation 1 are likely to be endogenous to, or simultaneously determined with, the fiscal policy outcomes. This risk is especially pronounced in the case of the relationship between tax collection and shadow economy. ${ }^{26}$ As demonstrated by Torgler (2003) and others, institutional factors - such as trust in the legal system and governmenthave a significant impact on tax morale. A number of other studies have documented the link between tax morale and tax collection on one hand (e.g., Cummings et. al., 2005), ${ }^{27}$ and tax morale and the shadow economy on the other hand (e.g., Alm and Torgler, 2004). Unless controlled for in the regressions, the resulting (spurious) correlation between tax collection and the shadow economy is likely to bias the coefficient estimates. It would have been desirable to control for tax morale, but we were unable to do so due to the limited coverage of this indicator across the sample countries and periods.

\footnotetext{
${ }^{26}$ See Auriol and Wartlers (2005) for a theoretical model and empirical results showing that both revenue collection and shadow economic activity are simultaneously determined by market entry fees. In addition, many of the existing measures of shadow economy are derived from the tax data.

${ }^{27}$ For studies discussing this link in the Armenian context, see McGree (1999) and McGee and Maranjyan (2006).
} 


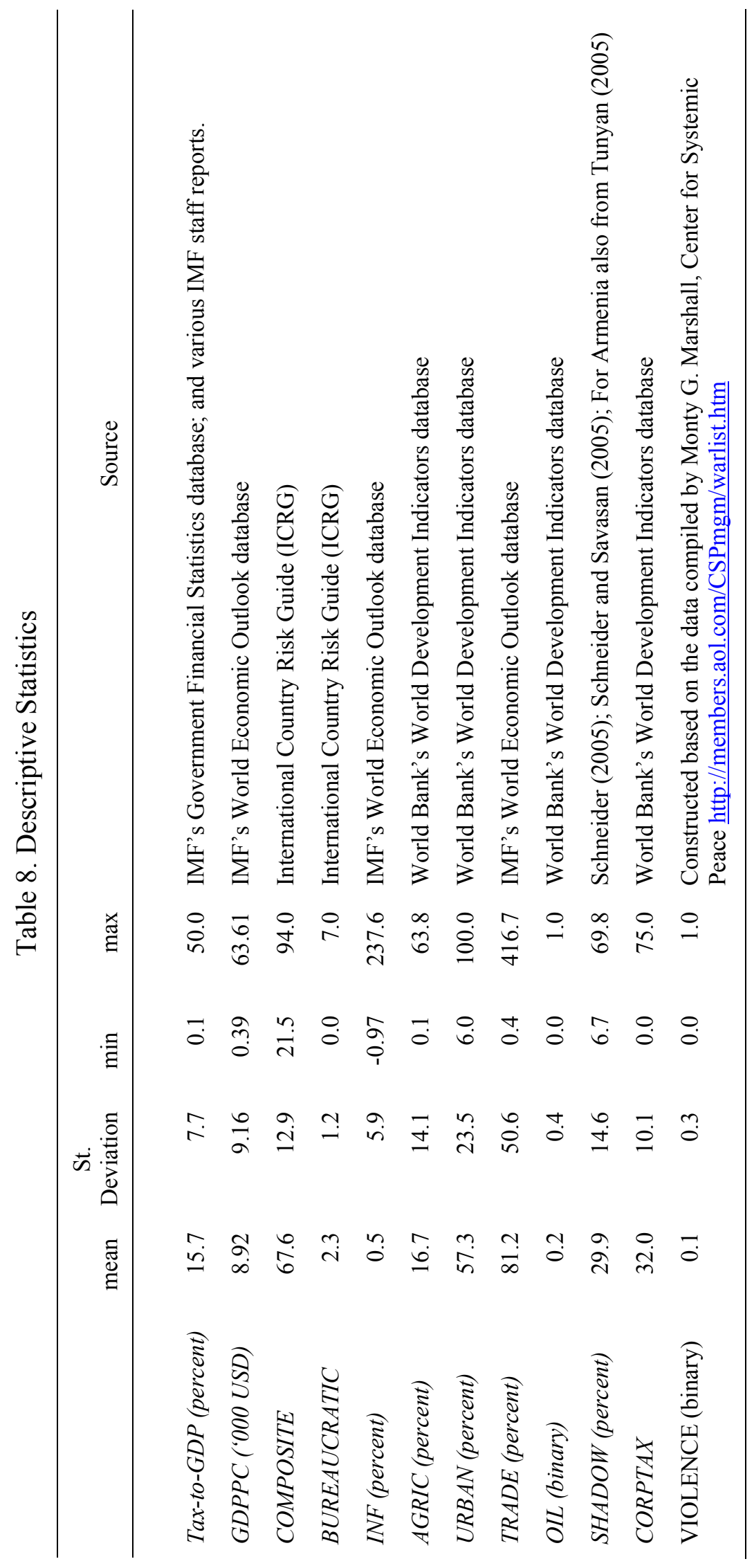


To detect any potential simultaneity between the tax effort and the shadow economy-both perhaps caused by the quality of institutions - we use the instrumental variable approach. We follow Schneider (2005) and others in assuming that differences in the shadow economy across countries could be explained by the differences in tax (and social security contribution) burden; quality of institutions (or more precisely, intensity/enforcement of regulations); quality and quantity of public sector services; and income level. To proxy for the tax burden, we used the highest marginal corporate tax rate, CORPTAX, across countries as reported by the World Bank. ICRG's composite measure of the quality of institutions, COMPOSITE, was used as a proxy for institutional development as well as of social services provision. To capture any potential non-linearity between quality of institutions and shadow economy, we added the squared value of this indicator, COMPOSITE-SQ, as a regressor. To account for the impact of political/social violence on the incentives of the private sector to go underground, we included a dummy variable VIOLENCE, compiled using the dataset provided by the Center for Systemic Peace. ${ }^{28}$ A positive sign is expected for the estimated coefficient on VIOLENCE.

The results of the first stage regression are presented in Table 9. The random effects specification (column 2) was rejected in favor of fixed effects specification (column 3). ${ }^{29}$ The OLS specification contained in column 1 is reported for comparison purposes only. As expected, countries with a higher level of GDP per capita have lower levels of shadow activity. Similarly, while the coefficient on VIOLENCE is not significant (with the exception of one specification, see below), it is positive, suggesting that countries with a lower level of political and social conflict are likely to have lower levels of shadow activity. The coefficients on COMPOSITE and COMPOSITE-SQ suggest that, while improvements in bureaucratic quality reduce the incentives to go underground, this impact is likely to be lower, the higher the level of institutional quality. Oddly enough, the coefficient on CORPTAX is negative suggesting that excessively high tax rates may reduce incentives to join the shadow economy, a finding that has also been reported in other studies of the shadow economy (e.g., Friedman et. al., 2000). This finding may imply that the benefits of higher tax rates may actually outweigh the costs of avoiding them (especially if they are accompanied by stricter punishments for non-compliance). Finally, the negative and significant impact of inflation, as a proxy for the quality of macroeconomic management, on the shadow economy is consistent with the observation that the inflation tax is faced by every individual regardless of whether one operates in the shadow economy. As a result, there is every reason to make use of public goods and services by joining the formal sector when inflation is high rather than when it is low.

\footnotetext{
${ }^{28}$ VIOLENCE takes a value of 1 if the country is reported to have had a conflict in a given year and 0 otherwise.

${ }^{29}$ The Hausman test had a p-value of 0.000 .
} 
Table 9. First Stage Panel Regression Results Dependent Variable Shadow Economy as a percent of GDP

\begin{tabular}{|c|c|c|c|c|c|}
\hline & \multirow{2}{*}{$\frac{\text { OLS }}{(1)}$} & \multirow{2}{*}{$\frac{\text { Random Effects }}{(2)}$} & \multicolumn{3}{|c|}{ Fixed Effects } \\
\hline & & & (3) & (4) & (5) \\
\hline \multirow[t]{2}{*}{ Time trend } & 0.958 & 0.718 & 0.676 & 0.783 & 0.733 \\
\hline & $(8.46)^{* * *}$ & $(17.05)^{* * *}$ & $(15.59)^{* * *}$ & $(17.94)^{* * *}$ & $(18.13)^{* * *}$ \\
\hline \multirow[t]{2}{*}{$G D P P C$} & -0.001 & -0.001 & -0.001 & -0.001 & -0.001 \\
\hline & $(10.38)^{* * *}$ & $(12.27)^{* * *}$ & $(10.85)^{* * *}$ & $(12.76)^{* * *}$ & $(12.12)^{* * *}$ \\
\hline \multirow[t]{2}{*}{ COMPOSITE } & -0.210 & -0.287 & -0.248 & & -0.254 \\
\hline & $(2.92)^{* * *}$ & $(2.25)^{* * *}$ & $(1.94)^{*}$ & & $(2.12)^{* *}$ \\
\hline \multirow[t]{2}{*}{ COMPOSITE-SQ } & & 0.003 & 0.002 & & 0.002 \\
\hline & & $(2.79)^{* * *}$ & $(2.59)^{* *}$ & & $(2.84)^{* * *}$ \\
\hline \multirow[t]{2}{*}{ BUREAUCRATIC } & & & & -7.006 & \\
\hline & & & & $(4.57)^{* * *}$ & \\
\hline \multirow{2}{*}{ BUREAUCRATIC-SQ } & & & & 1.249 & \\
\hline & & & & $(4.92)^{* * *}$ & \\
\hline \multirow[t]{2}{*}{ CORPTAX } & -0.135 & -0.055 & -0.052 & -0.059 & \\
\hline & $(2.89)^{* * *}$ & $(3.92)^{* * *}$ & $(3.68)^{* * *}$ & $(3.96)^{* * *}$ & \\
\hline \multirow[t]{2}{*}{$I N F$} & -0.805 & -1.291 & -1.337 & -0.414 & -1.326 \\
\hline & $(1.12)$ & $(8.44)^{* * *}$ & $(8.78)^{* * *}$ & $(8.82)^{* * *}$ & $(8.98)^{* * *}$ \\
\hline \multirow[t]{2}{*}{ VIOLENCE } & 1.556 & 0.415 & 0.256 & 1.432 & 0.222 \\
\hline & $(0.80)$ & $(0.63)$ & $(0.39)$ & $(2.14)^{* *}$ & $(0.37)$ \\
\hline \multirow[t]{2}{*}{ Latin America } & 2.816 & 6.060 & & & \\
\hline & $(2.66)^{* * *}$ & $(2.26)^{* *}$ & & & \\
\hline \multirow[t]{2}{*}{ Asia Pacific } & -4.488 & -3.155 & & & \\
\hline & $(4.17)^{* * *}$ & $(1.12)$ & & & \\
\hline \multirow[t]{2}{*}{ Middle East and Central Asia } & -2.809 & -0.482 & & & \\
\hline & $(2.08)^{* *}$ & $(0.16)$ & & & \\
\hline \multirow[t]{2}{*}{ Africa } & 2.445 & 5.484 & & & \\
\hline & $(1.50)$ & $(1.57)$ & & & \\
\hline \multirow[t]{2}{*}{ Low Income Countries } & -0.227 & 6.699 & & & \\
\hline & $(0.13)$ & $(2.36)^{* *}$ & & & \\
\hline \multirow[t]{2}{*}{ Low Middle Income Countries } & 4.112 & 9.026 & & & \\
\hline & $(3.29)^{* * *}$ & $(4.08)^{* * *}$ & & & \\
\hline \multirow[t]{2}{*}{ Constant } & 47.644 & 34.160 & 34.931 & 38.164 & 33.381 \\
\hline & $(8.32)^{* * *}$ & $(6.83)^{* * *}$ & $(7.52)^{* * *}$ & $(17.60)^{* * *}$ & $(7.88)^{* * *}$ \\
\hline Observations & 526 & 526 & 526 & 541 & 589 \\
\hline Number of countries & 115 & 115 & 115 & 116 & 136 \\
\hline R-squared & 0.72 & 0.68 & 0.65 & 0.68 & 0.65 \\
\hline
\end{tabular}

Absolute value of $t$ statistics in parentheses.

Note: $*$ implies significance at 10 percent; ** at 5 percent; *** at 1 percent confidence level.

To test for the robustness of these results, we also replaced COMPOSITE with the ICRG measure of quality of bureaucracy (BUREAUCRATIC). Results are similar to those obtained using COMPOSITE and are reported in column 4. Finally, in column 5 we reported the outcome of the regression without the CORPTAX, the variable with the smallest number of observations. While not significantly different from the results reported in columns 1-4, this 
specification allows for the use of a much larger sample of countries, a feature that makes this specification attractive for use in robustness tests in the second stage regressions below. Specifications 3 and 5 were used to get the fitted values of the dependent variables denoted by $S H A D O W$-hat and SHADOW-hat2, respectively, to be used for an estimation of equation $1 .^{30}$ With this in mind, we now turn to the discussion of the main results. The results of the estimation of equation 1 are reported in Table 10. Again, the fixed-effects model was picked (column 2). ${ }^{31}$ All key variables of interest have the predicted signs. ${ }^{32}$ As hypothesized, the effect of per capita income $(G D P P C)$ on tax collection is positive and is consistent with the results of most studies cited above. ${ }^{33}$ As expected, the impact of institutional quality on tax collection is positive and significant. This is consistent with the findings of Tanzi and Davoodi (2000) and Bird, Martinez-Vazquez, and Torgler (2004) and provides evidence of a direct channel for the impact of institutions on tax collection (apart from the indirect impact that institutions have through shadow economic activity). Regarding the impact of the shadow economy, here again the (negative) sign and significance are as expected. Its magnitude implies approximately a 1.5 percent of GDP increase in tax collection for every 10 percentage point drop in the shadow economy ratio.

The negative sign on INF confirms our expectations regarding the detrimental impact of inflation on tax collection and is consistent with the results reported by Agbeyegbe, Stotsky, and WoldeMariam (2004). The coefficient on $U R B A N$ is both positive and significant, confirming our hypothesis on the impact of the demand for public services on tax collection. The coefficient on $A G R I C$ is positive in most specifications (also see below) but is not significant. While running contrary to common belief, this result is not uncommon in the literature, with some studies even reporting a significant (positive) impact of agriculture on tax collection (e.g., Bird, Martinez-Vazquez, and Torgler, 2004). Similarly, the coefficient on $T R A D E$ is positive but not significant. This is consistent with Combes and Saadi-Sedik (2006), who report that (in developing countries) the negative impact of trade openness on budget balances is typically more than offset by trade-induced improvements in institutions and tax administration. ${ }^{34}$ Finally, the impact of OIL on tax collection is not conclusive, presumably because of the oil sector tax regime (and not because of the inability to collect taxes): in some oil-exporting countries oil revenue is collected in the form of royalties (which may not be classified as tax revenue), instead of taxes on oil companies. Hence the low level of the tax-to-GDP ratio despite the presence of oil resources.

${ }^{30}$ Given the limited number of observations for $S H A D O W$, the out-of-sample fit was used to generate $S H A D O W$-hat and SHADOW-hat2. The results obtained using the in-sample fit are not qualitatively different and are available from the authors upon request.

${ }^{31}$ As before, the Hausman test had a p-value of 0.000 .

${ }^{32}$ While the overall fit of the fixed effect regressions is low, this is due to the de-meaning procedure that STATA uses to run the fixed effects regressions. The equivalent Least Squares Dummy Variable (LSDV) regressions have R-squared exceeding 90 percent.

${ }^{33}$ The coefficient is significant when a logarithm of GDPPC is used instead.

${ }^{34}$ However, as discussed in Keen and Simone (2004), trade taxes - a component of total taxes - are likely to decrease if the liberalization progresses beyond a threshold. 
Table 10. Second Stage Panel Regression Results Dependent Variable:

Total Tax Revenue as a percent of GDP

\begin{tabular}{|c|c|c|c|c|c|}
\hline & \multirow{2}{*}{$\frac{\text { Random Effects }}{(1)}$} & \multicolumn{4}{|c|}{ Fixed Effects } \\
\hline & & (2) & (3) & (4) & (5) \\
\hline \multirow[t]{2}{*}{$G D P P C$} & 0.00003 & 0.00003 & 0.00003 & 0.00003 & 0.00003 \\
\hline & $(1.31)$ & $(1.27)$ & $(1.25)$ & $(1.03)$ & $(1.01)$ \\
\hline \multirow[t]{2}{*}{ COMPOSITE } & 0.055 & 0.058 & 0.059 & 0.056 & 0.056 \\
\hline & $(4.57)^{* * *}$ & $(4.75)^{* * *}$ & $(4.85)^{* * *}$ & $(4.40)^{* * *}$ & $(4.41)^{* * *}$ \\
\hline \multirow[t]{2}{*}{ SHADOW-hat } & -0.090 & -0.148 & -0.150 & -0.148 & -0.149 \\
\hline & $(2.57)^{* *}$ & $(3.49)^{* * *}$ & $(3.55)^{* * *}$ & $(3.30)^{* * *}$ & $(3.32)^{* * *}$ \\
\hline \multirow[t]{2}{*}{$I N F$} & -0.120 & -0.197 & -0.201 & -0.169 & -0.171 \\
\hline & $(2.34)^{* *}$ & $(3.28)^{* * *}$ & $(3.34)^{* * *}$ & $(2.30)^{* *}$ & $(2.32)^{* *}$ \\
\hline \multirow[t]{2}{*}{ OIL } & -0.342 & 0.554 & 0.558 & -1.232 & -1.234 \\
\hline & $(0.35)$ & $(0.50)$ & $(0.50)$ & $(0.87)$ & $(0.87)$ \\
\hline \multirow[t]{2}{*}{$A G R I C$} & -0.012 & 0.001 & 0.007 & 0.001 & 0.002 \\
\hline & $(0.52)$ & $(0.05)$ & $(0.28)$ & $(0.05)$ & $(0.09)$ \\
\hline \multirow[t]{2}{*}{$U R B A N$} & 0.067 & 0.158 & 0.160 & 0.174 & 0.175 \\
\hline & $(2.27)^{* *}$ & $(3.72)^{* * *}$ & $(3.78) * * *$ & $(3.79) * * *$ & $(3.81)^{* * *}$ \\
\hline \multirow[t]{2}{*}{ TRADE } & 0.004 & 0.001 & 0.001 & 0.000 & 0.000 \\
\hline & $(0.87)$ & $(0.17)$ & $(0.23)$ & $(0.05)$ & (0.03) \\
\hline \multirow[t]{2}{*}{ Armenia-1997 } & & & 3.882 & 3.744 & 3.394 \\
\hline & & & $(2.12)^{* *}$ & $(2.08)^{* *}$ & $(1.75)^{*}$ \\
\hline \multirow[t]{2}{*}{ Armenia-1999 } & & & 1.907 & 2.106 & 2.466 \\
\hline & & & (1.05) & (1.18) & (1.28) \\
\hline \multirow[t]{2}{*}{$R E A L G R$} & & & & 2.401 & 2.389 \\
\hline & & & & $(3.02)^{* * *}$ & $(3.00)^{* * *}$ \\
\hline \multirow{2}{*}{ Armenia * REALGR } & & & & & 0.637 \\
\hline & & & & & $(0.50)$ \\
\hline \multirow[t]{2}{*}{ Latin America } & -7.326 & & & & \\
\hline & $(4.01)^{* * *}$ & & & & \\
\hline \multirow[t]{2}{*}{ Asia Pacific } & -5.038 & & & & \\
\hline & $(2.56)^{* *}$ & & & & \\
\hline \multirow[t]{2}{*}{ Middle East and Central Asia } & -8.858 & & & & \\
\hline & $(4.51)^{* * *}$ & & & & \\
\hline \multirow[t]{2}{*}{ Africa } & 0.152 & & & & \\
\hline & $(0.07)$ & & & & \\
\hline \multirow[t]{2}{*}{ Low Income Countries } & 2.561 & & & & \\
\hline & $(1.18)$ & & & & \\
\hline \multirow[t]{2}{*}{ Low-Middle Income Countries } & 3.770 & & & & \\
\hline & $(2.33)^{* *}$ & & & & \\
\hline \multirow[t]{2}{*}{ Constant } & 12.99 & 7.17 & 6.91 & 6.69 & 6.62 \\
\hline & $(5.77)^{* * *}$ & $(3.53)^{* * *}$ & $(3.40)^{* * *}$ & $(3.06)^{* * *}$ & $(3.02)^{* * *}$ \\
\hline Observations & 1132 & 1132 & 1132 & 1078 & 1078 \\
\hline Number of countries & 118 & 118 & 118 & 118 & 118 \\
\hline R-squared & 0.34 & 0.04 & 0.05 & 0.05 & 0.05 \\
\hline
\end{tabular}

Note: $*$ implies significance at 10 percent; ${ }^{* *}$ at 5 percent; *** at 1 percent confidence level.

Absolute value of $t$ statistics in parentheses. 
To capture the effect of the switch to the destination principle for trade within CIS countries in 1997 and the one-off adjustment to the 1999 year (as discussed above), we included two dummy variables in the regressions (columns 3-5): Armenia-1997 takes value of 1 for 19972004, and 0 otherwise, while Armenia-1999 takes value of 1 for 1999, and 0 otherwise. The coefficients on both variables suggest that the move toward the destination principle may have permanently increased the tax collection in Armenia by approximately 3.4-3.9 percent of GDP, while the extension of the 1999 tax year into 2000 may have overstated the tax revenue in 1999 by as much as 1.9-2.5 percent of GDP

Perhaps more interestingly, we also tested for the hypothesis that during the episodes of fast growth countries collect less in taxes because tax administrations are usually slow to adjust in adequately covering the tax base. ${ }^{35}$ A dummy variable $R E A L G R$ was added to test this hypothesis, taking a value of 1 if a country's real GDP growth exceeds 10 percent in a given year and 0 otherwise. ${ }^{36}$ The sign and significance of the coefficient on REALRG (taken individually and interacted with the Armenia country dummy variable) suggest that (1) contrary to expectations, high-growth countries collect more revenues during high-growth episodes than otherwise; and (2) during its high-growth years, Armenia collected 0.6 percent of GDP more in taxes than other countries with high growth. ${ }^{37}$ Viewed together, these findings refute the claims that Armenia's low tax-to-GDP ratio could partly be caused by the fast growth of its economy in recent years.

Finally, we tested for the hypothesis that Armenia's direct tax revenue buoyancy lags behind that of other countries and the CIS 11 (as discussed in Section II). For that, we slightly modified equation 1 to have $(\log )$ nominal values of direct taxes as the dependent variable, added (log) nominal GDP as a regressor, and interacted it with CIS11 and Armenia dummies. While the estimated coefficient on the former interaction term turned out to be positive (suggesting that CIS11 countries have an above-average direct tax buoyancy), the coefficient on the latter interacted term was negative. This suggests that even after controlling for other determinants of tax revenue, the results in Table 7 hold. ${ }^{38}$

Next, we run a number of additional regressions to test for the robustness of the results, (see Table 11). First, we attempted to control for problems in the error term: the regression outcome reported in column 1 controls for heteroskedasticity (i.e., contains estimates of $t$ statistics based on heteroskedasticity-consistent standard errors), while that reported in column 2 controls for autocorrelation (i.e., allows for first order serial correlation in residuals within groups). In regression 3, we replaced $S H A D O W$-hat with $S H A D O W$-hat2, which is derived as discussed above. Finally, regression 4 contains results based on a truncated

\footnotetext{
${ }^{35}$ This hypothesis is often raised by the Armenian authorities in the context of policy discussions with the IMF on tax administration as a possible explanation for low tax collection.

${ }^{36}$ The choice of the threshold for the dummy variable was driven by the fact that Armenia's GDP growth in recent years was above 10 percent.

${ }^{37}$ This difference is not statistically significant, however.

${ }^{38}$ These results are available from the authors upon request.
} 
sample: only observations with values of the dependent variable falling within the range of plus/minus one standard deviation from its mean are included in the regression. All regressions in Table 11 produce qualitatively similar results across all coefficient estimates with continued significance and expected signs on the measure of institutional quality and shadow economy.

Table 11. Robustness Tests I

Dependent Variable: Total Tax Revenue as a percent of GDP

\begin{tabular}{|c|c|c|c|c|}
\hline & Robust SE & Corrected for AR(1) & without CORPTAX & Truncated Sample \\
\hline & (1) & (2) & (3) & (4) \\
\hline \multirow[t]{2}{*}{ GDPPC } & 0.00003 & 0.00003 & 0.00002 & 0.00005 \\
\hline & $(1.15)$ & $(0.58)$ & $(0.94)$ & $(1.37)$ \\
\hline \multirow[t]{2}{*}{ COMPOSITE } & 0.059 & 0.059 & 0.041 & 0.046 \\
\hline & $(4.09)^{* * *}$ & $(3.03)^{* * *}$ & $(3.93)^{* * *}$ & $(3.93)^{* * *}$ \\
\hline \multirow[t]{2}{*}{ SHADOW-hat } & -0.150 & -0.150 & & \\
\hline & $(2.92)^{* * *}$ & $(1.59)$ & & \\
\hline \multirow[t]{2}{*}{ SHADOW-hat2 } & & & -0.106 & -0.165 \\
\hline & & & $(2.75)^{* * *}$ & $(3.75)^{* * *}$ \\
\hline \multirow[t]{2}{*}{$I N F$} & -0.201 & -0.201 & -0.137 & -0.222 \\
\hline & $(2.84)^{* * *}$ & $(1.55)$ & $(2.48)^{* *}$ & $(3.56)^{* * *}$ \\
\hline \multirow[t]{2}{*}{$O I L$} & 0.558 & 0.558 & 0.670 & 3.328 \\
\hline & $(0.44)$ & $(0.35)$ & $(0.58)$ & $(1.93)^{*}$ \\
\hline \multirow{2}{*}{$A G R I C$} & 0.007 & 0.007 & -0.003 & 0.013 \\
\hline & $(0.21)$ & $(0.12)$ & $(0.13)$ & $(0.59)$ \\
\hline \multirow{2}{*}{$U R B A N$} & 0.160 & 0.160 & 0.144 & 0.150 \\
\hline & $(3.75)^{* * *}$ & $(2.02)^{* *}$ & $(3.51)^{* * *}$ & $(3.47)^{* * *}$ \\
\hline \multirow[t]{2}{*}{ TRADE } & 0.001 & 0.001 & 0.007 & 0.017 \\
\hline & $(0.15)$ & $(0.08)$ & $(1.45)$ & $(3.23)^{* * *}$ \\
\hline \multirow[t]{2}{*}{ Armenia-1997 } & 3.882 & 3.882 & 3.731 & 4.045 \\
\hline & $(8.49)^{* * *}$ & $(7.67)^{* * *}$ & $(1.96)^{*}$ & $(2.29)^{* *}$ \\
\hline \multirow[t]{2}{*}{ Armenia-1999 } & 1.907 & 1.907 & 1.968 & 1.880 \\
\hline & $(5.68)^{* * *}$ & $(15.03)^{* * *}$ & (1.04) & $(1.07)$ \\
\hline \multirow[t]{2}{*}{ Constant } & 6.91 & 6.91 & 7.55 & 6.88 \\
\hline & $(3.15)^{* * *}$ & (1.59) & $(4.18)^{* * *}$ & $(3.72)^{* * *}$ \\
\hline Observations & 1132 & 1132 & 1361 & 1044 \\
\hline Number of countries & 118 & 118 & 141 & 119 \\
\hline R-squared & 0.05 & 0.05 & 0.04 & 0.05 \\
\hline
\end{tabular}

Note: * implies significance at 10 percent; ** at 5 percent; *** at 1 percent confidence level.

Absolute value of $t$ statistics in parentheses. 
Table 12. Robustness Tests II

Dependent Variable: Total Tax Revenue as a percent of GDP

\begin{tabular}{|c|c|c|c|c|c|c|c|c|}
\hline & OECD & LMC & LIC & EUR & LAC & APD & MCD & AFR \\
\hline & (1) & (2) & (3) & (4) & (5) & (6) & (7) & (8) \\
\hline \multirow[t]{2}{*}{$G D P P C$} & 0.0001 & 0.0011 & 0.0002 & 0.0002 & 0.0000 & 0.0000 & 0.0008 & 0.00042 \\
\hline & $(3.88)^{* * *}$ & $(4.80)^{* * *}$ & $(0.23)$ & $(5.43)^{* * *}$ & $(0.22)$ & $(0.40)$ & $(3.37)^{* * *}$ & $(1.21)$ \\
\hline \multirow[t]{2}{*}{ COMPOSITE } & 0.055 & 0.040 & 0.051 & 0.006 & 0.080 & 0.060 & 0.089 & 0.055 \\
\hline & $(1.43)$ & $(2.29)^{* *}$ & $(1.87)^{*}$ & $(0.22)$ & $(4.31)^{* * *}$ & $(2.69)^{* * *}$ & $(3.51)^{* * *}$ & $(1.81)^{*}$ \\
\hline \multirow[t]{2}{*}{ SHADOW-hat } & -0.018 & -0.222 & -0.186 & -0.026 & -0.255 & -0.094 & -0.493 & 0.019 \\
\hline & $(0.20)$ & $(2.43)^{* *}$ & $(1.43)$ & $(0.37)$ & $(2.75)^{* * *}$ & $(0.81)$ & $(5.05)^{* * *}$ & $(0.13)$ \\
\hline \multirow[t]{2}{*}{$I N F$} & -1.735 & -0.288 & -0.195 & -0.042 & -0.336 & 1.177 & -3.162 & 0.080 \\
\hline & $(0.34)$ & $(2.33)^{* *}$ & $(1.06)$ & $(0.23)$ & $(2.72)^{* * *}$ & $(0.72)$ & $(2.73)^{* * *}$ & $(0.39)$ \\
\hline \multirow[t]{2}{*}{ OIL } & & & -1.268 & & & 3.954 & -4.290 & \\
\hline & & & $(0.69)$ & & & $(2.79)^{* * *}$ & $(2.97)^{* * *}$ & \\
\hline \multirow{2}{*}{$A G R I C$} & -0.047 & 0.028 & 0.000 & 0.125 & 0.278 & 0.260 & -0.158 & -0.012 \\
\hline & $(0.22)$ & $(0.71)$ & $(0.01)$ & $(2.12)^{* *}$ & $(4.02)^{* * *}$ & $(3.00)^{* * *}$ & $(2.46) * *$ & $(0.31)$ \\
\hline \multirow[t]{2}{*}{$U R B A N$} & 0.100 & 0.133 & 0.133 & 0.168 & 0.546 & 0.359 & 0.126 & -0.011 \\
\hline & $(1.66)^{*}$ & $(1.66)^{*}$ & $(1.02)$ & $(2.75)^{* * *}$ & $(4.31)^{* * *}$ & $(3.50)^{* * *}$ & $(1.23)$ & $(0.08)$ \\
\hline \multirow[t]{2}{*}{ TRADE } & -0.044 & 0.004 & 0.048 & -0.061 & 0.014 & -0.048 & 0.026 & 0.061 \\
\hline & $(3.64)^{* * *}$ & $(0.40)$ & $(4.27)^{* * *}$ & $(6.57)^{* * *}$ & $(1.52)$ & $(3.97)^{* * *}$ & $(1.89)^{*}$ & $(5.25)^{* * *}$ \\
\hline \multirow[t]{2}{*}{ Armenia-1997 } & & 3.121 & & & & & 2.143 & \\
\hline & & $(1.99)^{* *}$ & & & & & $(1.48)$ & \\
\hline \multirow[t]{2}{*}{ Armenia-1999 } & & 2.581 & & & & & 2.232 & \\
\hline & & $(1.69)^{*}$ & & & & & $(1.64)$ & \\
\hline \multirow[t]{2}{*}{ Constant } & 9.58 & 7.24 & 10.13 & 10.56 & -26.93 & -3.71 & 13.60 & 8.70 \\
\hline & $(1.37)$ & $(2.19)^{* *}$ & $(3.72)^{* * *}$ & $(2.26)^{* *}$ & $(3.71)^{* * *}$ & $(0.75)$ & $(2.93)^{* * *}$ & $(3.03)^{* * *}$ \\
\hline Observations & 279 & 299 & 263 & 361 & 214 & 155 & 165 & 237 \\
\hline Number of countries & 24 & 32 & 27 & 36 & 20 & 17 & 21 & 24 \\
\hline R-squared & 0.14 & 0.2 & 0.11 & 0.17 & 0.23 & 0.24 & 0.34 & 0.18 \\
\hline
\end{tabular}

Note: * implies significance at 10 percent; ** at 5 percent; *** at 1 percent confidence level. OECD-Organization for Economic Cooperation and Development, LMC — Low Middle Income countries, LIC — Low Income countries; EUR - Europe; LAC — Latin American and Caribbean; APD—Asia Pacific; MCD—Middle East and Central Asia; AFR-Africa. Absolute value of $t$ statistics in parentheses.

In a second round of robustness checks, and to test whether country/regional differences would account for a low regression fit, we run equation 1 for various regions and income groupings separately. While the values of R-squared reported in Table 12 are indeed higher, the differences in results across these groupings reveal much more. First of all, unlike in the overall sample, the impact of (i) institutions, (ii) shadow economic activity, and (iii) inflation on tax collection within the OECD countries becomes insignificant. This is explained by rather low levels of risks stemming from the above factors for tax collection, as explained above, as well as the limited variation in the values of these indicators among the OECD countries. ${ }^{39}$ Additionally, agriculture and trade openness have a negative impact on tax

\footnotetext{
${ }^{39}$ However, interestingly enough, the disparity in the income per capita is sufficient to result in a positive and significant relationship between the GDPPC and tax collection which may indicate the extent of the progressivity of income taxes and the predominance of direct taxes.
} 
collection, both consistent with the hypotheses outlined above. The former result could perhaps be due to the fact that, given the largely subsidized nature of agriculture in OECD countries, a larger share of agriculture implies more tax exemptions and, therefore, less tax revenues. For the latter result, since the marginal improvement in institutional quality and, as a result tax administration, are likely to be lower than in developing countries, countries in the OECD lack the offsetting factor of trade openness on tax collection à la Combes and Saadi-Sedik (2006).

Second, for the other extreme on the income scale, in Low Income Countries as a group, trade openness leads to higher tax-to-GDP ratios, and there seems to be no link between $U R B A N$ and tax collection. The former result could be attributed to the higher marginal improvement of institutions from trade, and the latter result could perhaps be due to lower levels of urban population in low income countries.

Third, interesting regional patterns emerge (columns 4-8) ranging from the impact of INF (where regions with a large number of countries with a high inflation history, LAC and MCD, seem to sustain a strong negative link between inflation and tax collection) to the impact of $U R B A N$ (where the link is insignificant and even turns negative in MCD and AFR, respectively).

\section{Post-estimation Analysis}

We use the results obtained above to estimate the potential tax-to-GDP ratio and construct a measure of tax effort across countries. Figure 5 depicts actual and potential (based on regression 3 from Table 10) tax-to-GDP ratios for 4 country groupings for 1990-2004: OECD, CIS1 1, Low Income Countries, and Low Middle Income Countries. It appears that for the sample period, the tax collection in OECD countries hovers around its potential. In contrast, Low Income and Low Middle Income countries collect more in taxes than what their characteristics would suggest. Interestingly, and consistent with Auriel and Wartlers (2005), the CIS countries (excluding Armenia) also collect more taxes than their potential levels.

The comparative relationship for Armenia for 1996-2006 is depicted on Panel 1, Figure 6 (2005 and 2006 values are out-of-sample predictions using estimated values of regressors where actual values were not available). Using the alternative specification with the larger sample (i.e., regression 3 in Table 11) to predict the same indicator results only in a difference of one-tenth of a percentage point of GDP on average for 1996-2004 (and less for more recent years), suggesting that the estimates are rather robust. The gap between actual and potential levels is equal to 6.4 percent of GDP on average between $1996-2006 .{ }^{40}$ It is important to note that despite the government's attempts to boost tax collection in recent years, the tax effort - the ratio of actual to potential tax collection, depicted in Panel 2, Figure 6-has been on a declining path since 2000.

\footnotetext{
${ }^{40}$ In nominal terms, this shortfall was approximately \$300 million and \$400 million in 2005 and 2006, respectively.
} 
Figure 5. Actual and Potential Tax-to-GDP Ratios for Select Country Groupings, 1990-2004
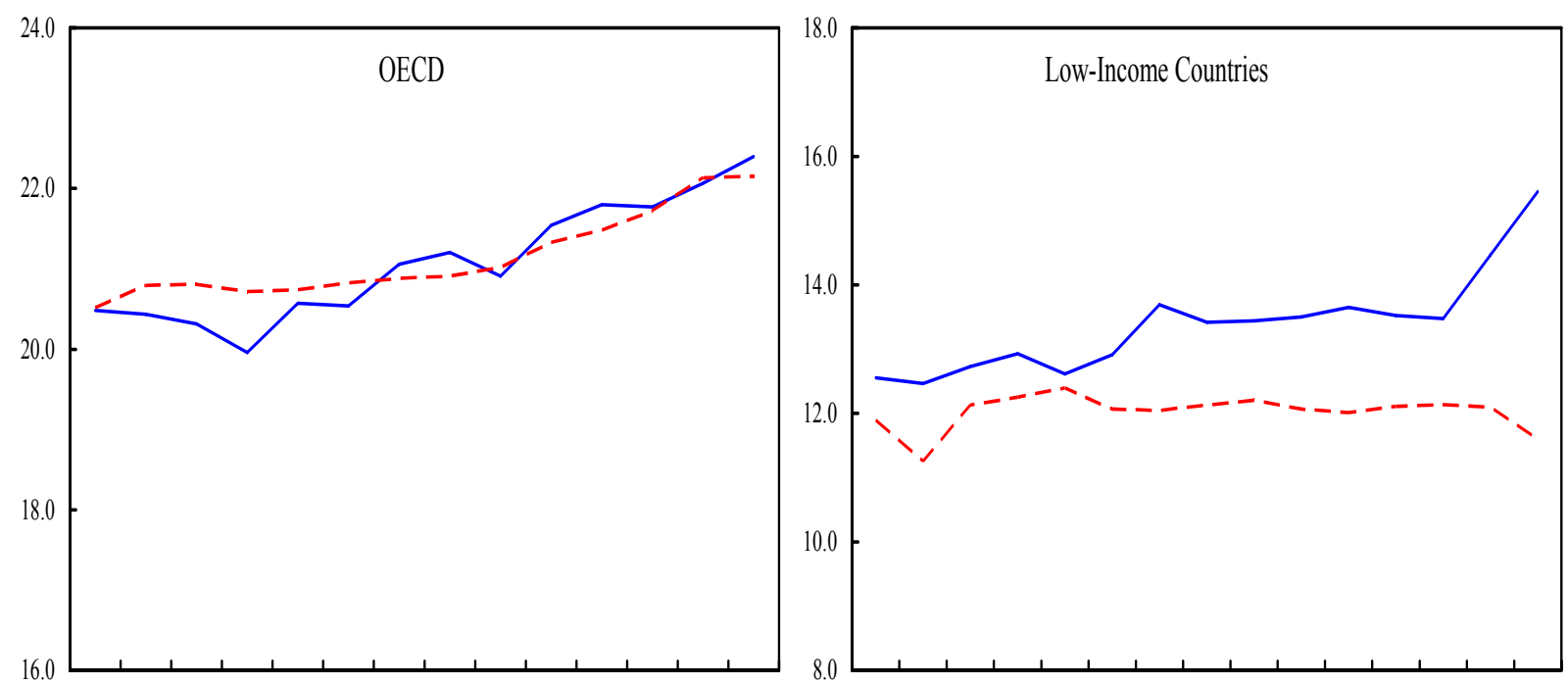

19901991199219931994199519961997199819992000200120022003

199019911992199319941995199619971998199920002001200220032004
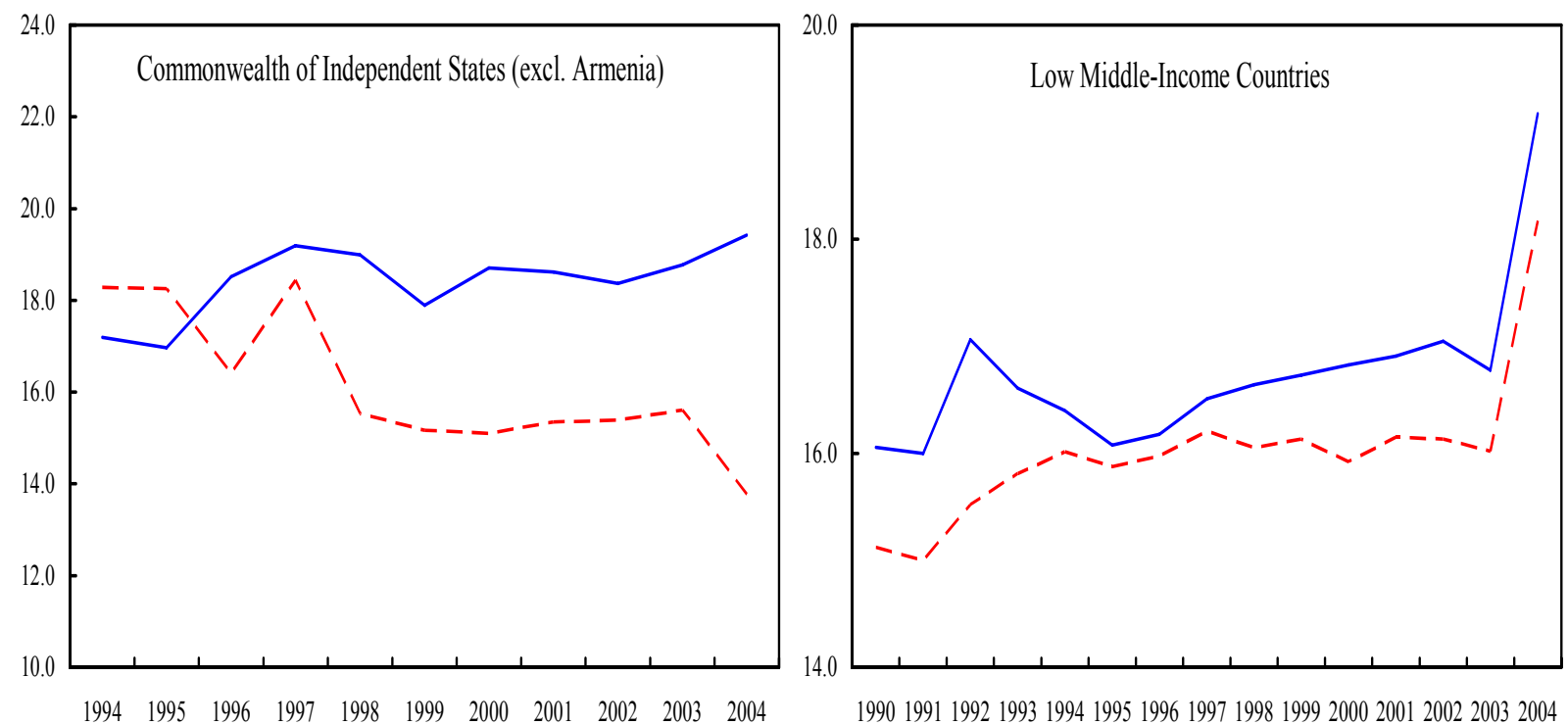

199019911992199319941995199619971998199920002001200220032004

Source: Fund Staff estimates. 
Figure 6. Armenia: Actual and Potential Tax Levels, and Tax Effort, 1996-2006
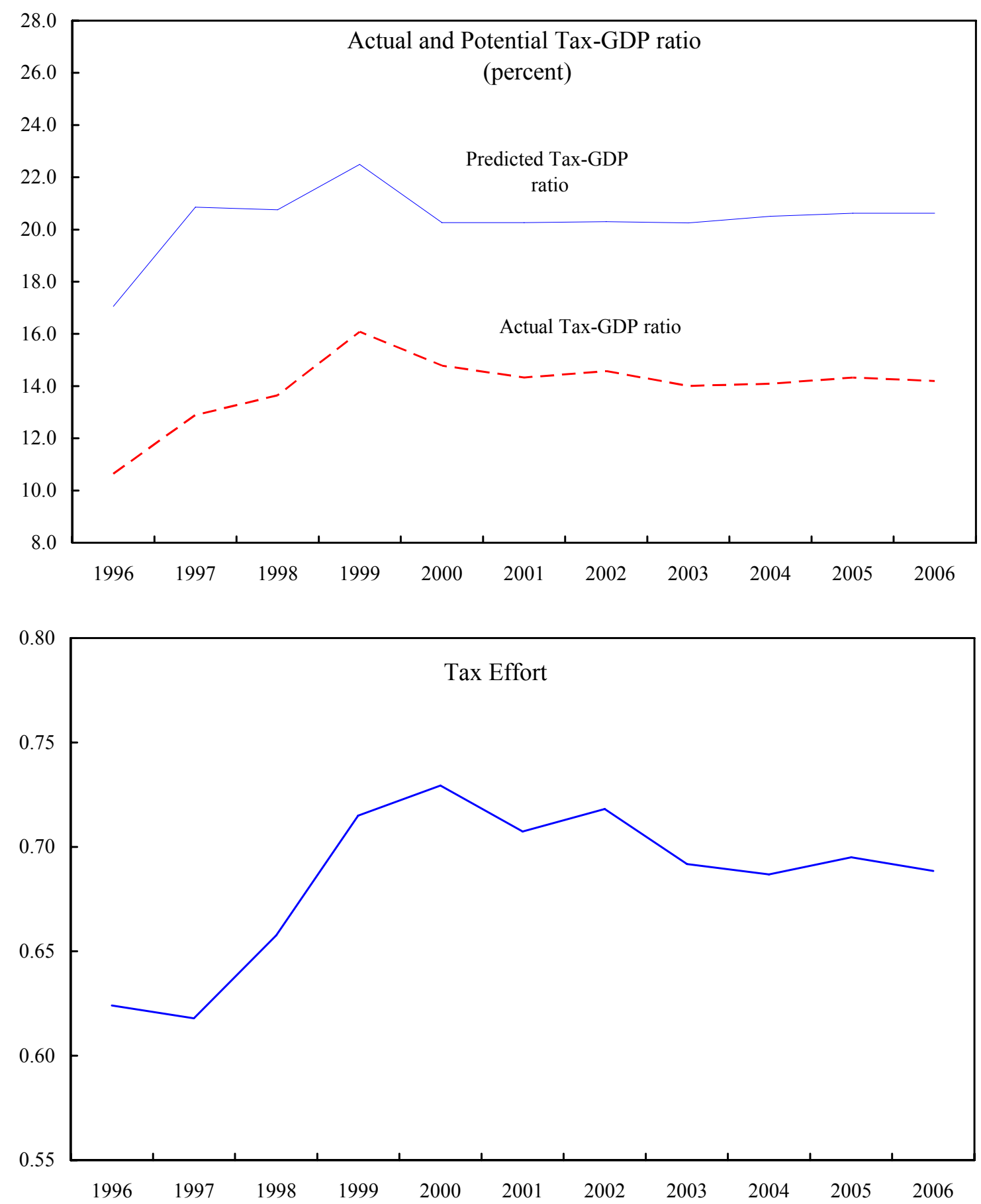

Source: Armenian authorities and own calculations.

Estimates of the potential tax-GDP ratio for 2005 and 2006 are based on assumptions of some independent variables, where their actual values are not yet available. 
The estimated contribution of each variable in the baseline regression shows that of the potential tax revenues of approximately $201 / 2$ percent of GDP, urbanization contributes the most (about 11 percent of GDP), followed by the shadow economy (5 1/2 percent of GDP) and quality of institutions (4 percent of GDP). The strong contribution of urbanization is consistent with a high demand for public services from roughly $2 / 3$ of Armenians who live in urban areas as well as concentration of economic activities in the urban sector in Armenia. ${ }^{41}$ However, its relatively sizable contribution as compared to actual collection of roughly $14 \frac{1}{2}$ percent of GDP also implies that little taxes are actually collected from the urban sector and related activities such as construction sector, which in Armenia is concentrated in and around the capital city.

While it is unlikely that policies will have much immediate impact on Armenia's disparity relative to other countries in terms of per capita income, share of urban population, or oil exports (i.e., some of the drivers behind the potential tax-to-GDP ratio), there are other factors that are very much in the policymaking realm. Specifically, policies aimed at improving governance and tax administration as well as enhancing the willingness to pay taxes will provide a much needed boost to Armenia's tax-to-GDP ratio. While, as suggested by the above regressions, tax collections could go up both directly (as a result of improvements in administration and tax coverage) and indirectly (through improvements in willingness to pay and reduction in shadow economic activity), improvements in governance and institutional quality lie at the heart of both channels.

If viewed through their impact on real activity and poverty reduction, policies and practices targeted at improving governance and the rule of law are likely to be much more powerful and have an impact going beyond that outlined above (see Rodrik, Subramanian, and Trebbi, 2002 and other articles in the burgeoning literature on the impact of institutions on economic activity). And as indicated earlier, while the efforts directed at improving tax policy and tax administration will help strengthen tax collection in Armenia, these are unlikely to result in the much-needed structural change if undertaken outside of a comprehensive package that also - and more importantly — targets improvements in the rule of law and institutional quality, and tax morale. Failure to aggressively reform 'societal' institutions governing the willingness to pay (or avoid) taxes and continued reliance on stand-alone and piecemeal administrative and policy changes (i.e., those without accompanying significant changes in institutions and governance) as in the past will not result in significant gains in tax collection in the future. These, however, are mostly in the domain of political will, which is outside of the scope of this paper.

\section{Conclusions}

In sum, improving institutions - defined broadly to include institutional weaknesses in tax and customs administration as well as other economic aspects of governance-is a viable option available to Armenia's policymakers wishing to permanently enhance the economy's

\footnotetext{
${ }^{41}$ Armenia ranks the seventh highest country in the world in terms of percent of urban population living in the country's largest metropolitan area, the capital (World Development Indicators, 2006). The top six countries include city-states such as Singapore, Honk Kong, and Puerto Rico.
} 
tax-generating capacity to meet the needs of the economy for infrastructure investments and social programs. As Bird, Martinez-Vazquez, and Torgler (2004) note, "while at first glance giving such advice to poor countries seeking to increase their tax ratios may not seem more helpful than telling them to find oil, it is presumably more feasible than to rearrange nature's bounty." We agree with this conclusion.

This paper documents Armenia's low tax-to-GDP ratio relative to a large number of benchmarks and shows that its persistently lower tax revenue buoyancy-particularly, income tax buoyancy - is a potential contributory factor. The tax-to-GDP ratio can also be increased significantly if Armenia improves its VAT productivity by broadening the base, removing exemptions, and improving its VAT refund mechanism to boost tax morale and reduce the willingness to stay in the informal, shadow economy.

The main contribution of the paper to the literature has been to extend the conventional determinants of tax potential to include measures of institutional quality and shadow economy in a panel data framework. The empirical analysis of the paper shows that Armenia's tax effort falls short of its potential by as much as $6 \frac{1}{2}$ percent of GDP and that improvements in institutions as well as policy measures designed to reduce the size of the shadow economy are important factors in boosting tax performance. While further work may be necessary to determine the exact channels of influence of institutions on tax collection and shadow economic activity - which presumably work through tax morale and cost of evasion-this paper helps document some of the above links and offers new clues for a more ambitious research agenda.

There are signs of a turn-around in Armenia's tax collection pattern in 2005-06 (i.e., beyond the period analyzed in the paper), though they would not change the thrust of our analysis. Beginning in 2004, the share of direct taxes in tax revenues has increased, reversing a trend decline since 1999. This reversal has in part contributed to a cumulative increase in tax-toGDP ratio of 0.7 percent of GDP since 2004, in spite of a noticeable decline in VAT performance. The increase in the tax-to-GDP ratio since 2004 continues to fall short of the PRGF program target and its implied buoyancy. The recent legislative amendments to tax the construction sector in 2007 and the agriculture sector in 2008 are steps in the right direction, but they also entail a stepped-up effort in improving the institutional working of the tax administration that is ultimately in charge of implementing the tax laws and collecting the stipulated tax receipts.

Looking ahead, it is clear that gains from improving the institutional structure of tax and customs administration in Armenia and governance in general can be permanent and sizable if there is a sustained political will to implement many laudable measures already identified by Fund staff and the Armenian authorities in the 2005-08 PRGF-supported program. ${ }^{42}$ Setting ambitious targets for tax collection for Armenia will be more effective and likely to be met in practice if the authorities are equally ambitious about implementing better fiscal institutions in Armenia on a lasting basis.

\footnotetext{
${ }^{42}$ See also IMF (2006), Chapter II.
} 


\section{REFERENCES}

Alm, J. and B. Torgler, 2004, "Culture Differences and Tax Morale in the United States and in Europe," Working Paper 04-14: Center for Research in Economics, Management, and the Arts (CREMA), Basel.

Agbeyegbe, T., J. Stotsky, and A. WoldeMariam, 2004, "Trade Liberalization, Exchange Rate Changes, and Tax Revenue in Sub-Saharan Africa," Working Paper No. 04/178: International Monetary Fund, Washington, DC.

Auriol, E. and M. Wartlers, 2005, "Taxation Base in Developing Countries," Journal of Public Economics 89, pp. 625-646.

Bahl, R. W., 1971, “A Regression Approach to Tax Effort and Tax Ratio Analysis," International Monetary Fund Staff Papers 18, pp. 570-612.

Baunsgaard, T., and M. Keen, 2005, "Tax Revenue and (or?) Trade Liberalization,” Working Paper 05/112: International Monetary Fund, Washington, DC.

Bird, R., J. Martinez-Vazquez, and B. Torgler, 2004, "Societal Institutions and Tax Effort in Developing Countries," Working Paper 04-06: International Studies Program, Andrew Young School of Policy Studies, Georgia State University.

Ebrill, L., M. Keen, J-P. Bodin and V. Summers, 2001, The Modern VAT (Washington D.C.: International Monetary Fund).

Combes, J-L, and T. Saadi-Sedik, 2006, "How Does Trade Openness Influence Budget Deficits in Developing Countries?" Working Paper 06/03: International Monetary Fund, Washington, DC.

Cummings, R., J. Martinez-Vazquez, M. McKee, and B. Torgler, 2005, "Effects of Tax Morale on Tax Compliance: Experimental and Survey Evidence," mimeo.

Friedman, E., S. Johnson, D. Kaufmann and P. Zoido-Lobaton, 2000, "Dodging the Grabbing Hand: The Determinants of Unofficial Activity in 69 countries," Journal of Public Economics, 76, pp.459-493.

Gelbard, E., J. McHugh, G. Iradian, C. Beddies, and L. Redifer, 2005, Growth and Poverty Reduction in Armenia, Achievements and Challenges, (Washington D.C: International Monetary Fund).

Hudson, J. and J. Teera, 2004, “Tax Performance: A Comparative Study,” Journal of International Development 16, No. 6, pp. 785-802. 
International Monetary Fund, 2006, "Republic of Armenia: Selected Issues," IMF Country Report No. 06/434, Washington D.C.

Joulfaian, D. and L. Melikyan, 2004, "Taxes, Incentives, and the Cost of Capital in Armenia," Armenian Journal of Public Policy 1, No. 2, pp. 213-232.

Keen, M. and A. Simone, 2004, "Tax Policy in Developing Countries," in S. Gupta, B. Clements, and G. Inchauste (eds.), Helping Countries Develop: The Role of Fiscal Policy, International Monetary Fund, pp. 302-352.

Leuthold, J. 1991, “Tax Shares in Developing Economies: A Panel Study,” Journal of Development Economics 35, pp. 173-85.

McGee, R., 1999, "Why People Evade Taxes in Armenia: A Look at an Ethical Issue Based on a Summary of Interviews," Journal of Accounting, Ethics and Public Policy 2, pp. 408-416.

McGee, R. and S. Maranjyan, 2006, “Tax Evasion in Armenia: An Empirical Study," Paper presented at the Fourth AIPRG Conference in Washington, DC, January 14-15, 2006.

Piancastelli, M., 2001, "Measuring the Tax Effort of Developed and Developing Countries: Cross-Country Panel Data Analysis, 1989-95," Discussion Paper: IPEA, Rio de Janeiro.

Rodrik, D., A. Subramanian, and F. Trebbi, 2002, "Institutions Rule: The Primacy of Institutions over Geography and Integration in Economic Development," CEPR Discussion Paper No. 3643.

Schneider, F., 2005, "Shadow Economies of 145 Countries all Over the World: What Do We Really Know?" mimeo.

Schneider F. and F. Savasan, 2005, "The Size of Shadow Economies of Turkey and of Her Neighboring Countries from 1999 to 2005," mimeo.

Stotsky, J. and A. WoldeMariam, 1997, “Tax Effort in Sub-Saharan Africa," Working Paper 97/107: International Monetary Fund, Washington, DC.

Tanzi, V., 1987, "Quantitative Characteristics of the Tax Systems of Developing Countries," in David Newbery and Nicholas Stern (eds), The Theory of Taxation in Developing Countries, Oxford University Press.

Tanzi, V. and H. Davoodi, 1997, “Corruption, Public Investment, and Growth,” Working Paper 97/139: International Monetary Fund, Washington, DC. 
Tanzi, V. and H. Davoodi, 2000, “Corruption, Growth, and Public Finances,” Working Paper 00/182: International Monetary Fund, Washington, DC.

Tanzi, V. and H. Zee, 2000, "Tax Policy in Emerging Markets: Developing Countries," Working Paper 00/35: International Monetary Fund, Washington, DC.

Torgler, B., 2003, “Tax Morale in Transition Countries", Post-Communism Economies Vol.15, No.3, pp. 357-381.

World Development Indicators, 2006, The World Bank, Washington, DC. 